\title{
Crust Biometry of Hydrolithon Boreale (Rhodophyta: Hydrolithaceae) on Leave of Posidonia Oceanica Along a Mediterranean Coast Fed by Siliciclastic- Carbonate
}

Erhan Mutlu ( $\nabla$ emutlu@akdeniz.edu.tr)

Akdeniz Üniversitesi: Akdeniz Universitesi https://orcid.org/0000-0002-6825-3587

Doğukan Karaca

Akdeniz Üniversitesi: Akdeniz Universitesi

Güler Sıla Duman

Akdeniz Üniversitesi: Akdeniz Universitesi

Ahmet Şahin

Karadeniz Technical University: Karadeniz Teknik Universitesi

Yaşar Özvarol

Akdeniz Üniversitesi: Akdeniz Universitesi

Cansu Olguner

Birey High School

\section{Research Article}

Keywords: Epiphyte, biometry, meadow, environmental correlation, Turkish Mediterranean coast

Posted Date: November 23rd, 2021

DOI: https://doi.org/10.21203/rs.3.rs-1008523/v1

License: (c) (i) This work is licensed under a Creative Commons Attribution 4.0 International License.

Read Full License 


\section{Abstract}

A study was conducted to estimate biometry of an epiphytic micro-calcareous red algae, Hydrolithon boreale found on leaves of a Mediterranean meadow, Posidonia oceanica along the entire Turkish coast of the Mediterranean Sea in time (winter and summer 2019) and space (regions, and bottom type and depth). Percent occurrence of the epiphyte was lower in winter (25\%), particularly found in a small bay in the west than summer (44\%), entirely along the coast. The epiphyte grew up to $5 \mathrm{~mm}$ in diameter, 0.35 $\mathrm{mm}$ in thickness of the crust size, and was populated up to $1006 \mathrm{ind} / \mathrm{m}^{2}$ in summer owing to the increased utilization of the carbonate by the epiphyte with the increased water temperature. The size was contrasted to the density (abundance and biomass) in space. The biometry was significantly dependent on the siliciclastic-carbonate deposition as inferred from $\mathrm{SiO}_{2}$ of the water in relation the leaf area index (LAI) of $P$. oceanica. Therefore, this deposition induced specimens growing in size, followed by the reduced density in relation to $\mathrm{N}$-based nutrient of the water. Further major environmental parameters which negatively affected the biometry were $\mathrm{pH}$ and total suspended matter of the water, analogous to the turbidity. Of the trace elements, $\mathrm{Ni}$ was negatively correlated with the biometry whereas the LAl was however positively correlated with all the anthropogenic-sourced trace elements ( $\mathrm{V}, \mathrm{Cu}, \mathrm{Zn}, \mathrm{As}, \mathrm{Cd}$, and $\mathrm{Pb})$ in the leaves. Of the bottom types, the calcite rock had higher density than the other soft bottoms in contrast to the size of the epiphyte.

\section{Introduction}

The epiphytes on the seagrass suggest ecological indications and status for the marine environments. As occurring at every taxon, the epiphytes have sensitive and tolerant species to the levels of the disturbance in the marine environments (Sfriso et al. 2007, 2009). Therefore, their density (abundance and biomass) and species composition showed direction and levels of the ecological conditions.

One of the sensitive seagrass in the Mediterranean Sea is a meadow, Posidonia oceanica (Linnaeus) Delile, 1813 and covered by diverse epiphytes hosted on its rhizomes and leaves (Nesti et al. 2009). The epiphytes and $P$. oceanica together are a good combination to asses and monitor the ecological conditions in the Mediterranean Sea. Besides, the epiphytes are food sources for the marine organisms, especially herbivorous species. The epiphytes are composed generally of their different species on the meadow (Havelange et al. 1997; Lepoint et al. 2000; Vizzini et al. 2002; Heck and Valentine 2006; Lepoint et al. 2006). Overall, the epiphytes are indication and intensity level of i.e. the eutrophication, productivity, the herbivory, trace chemical elements, acidification, ambience, anthropogenicality, seasonality, turbidity, warming, sedimentation, hydrodynamics and natural land sourcing around the marine environments in time and space (Bedini et al. 2003; Heck et al. 2006; Balata et al. 2008; Jacquemart and Demoulin 2008; Jaschinski and Sommer 2008; Baggett et al. 2010; Suarez et al. 2015; Brahim et al. 2020). In general, the epiphytes can be controlled through a process from top to down direction of the ecosystem by the herbivory, and from bottom to up direction, on a reverse way by the nutrient availability (Heck et al. 2006; Jaschinski and Sommer 2008; Baggett et al. 2010). 
One of the epiphyte taxa which are noticed and paid attention are the calcareous species which are acted as processors in the sediments (Walker and Woelkerling 1988). The most dominant encrusting species were Hydrolithon and Pneophyllum species as epiphytes on the seagrass in the Mediterranean Sea (Jacquemart and Demoulin 2008; Piazzi et al. 2000). Only these two genera species predicted reasonably most of the ecological indications (Mann 2001; Lepoint et al. 2007; Peterson et al. 2007; Tsirika et al. 2007; Mabrouk et al. 2013; Bermejo et al. 2016; Mabrouk et al. 2017; Prado 2018; Sfriso et al. 2014, $2016,2020)$ since they are very sensitive to change in the environments and common in undisturbed areas (Piazzi et al. 2002; Martinez-Crego et al. 2010; Bedini and Piazzi 2012; Brahim et al. 2020).

Main indication of the encrusting micro calcareous has been focused on the acidification process in relation of the carbonate to the $\mathrm{pH}$ in the Mediterranean Sea (e.g. Cox et al. 2015; Mutalipassi et al. 2020; Sfriso et al. 2020) due to the global warming. Such calcareous red algae utilized $\mathrm{HCO}_{3}$ via $\mathrm{CO}_{2}$ to precipitate $\mathrm{CaCO}_{3}$ in their tissues in the form of calcite deposited throughout the cell walls or aragonite (Mann 2001) in the Mediterranean Sea (Sfriso et al. 2020). The pH of the water inhibited the utilization (Fragoso et al. 2010). The targeted species in the present study, Hydrolithon spp had the highest coverage (18-69\%; Martin et al. 2008) on seagrass at a water pH of 8.1 (8.0-8.2) while there were no such epiphytes at $7.7 \mathrm{pH}$ (Martin et al. 2008; Mutalipassi et al. 2020) owing to a positive correlation between the coralline cover and epiphytic $\mathrm{CaCO}_{3}$ and pH (Martin et al. 2008). In the Mediterranean Sea, overall the decomposition of thionitrophilous taxa reduced $\mathrm{pH}$ values which slowed down the growth of small calcareous species such as Pneophyllum fragile Kützing, 1843 and Hydrolithon spp which cannot grow in poor-bad conditions (Sfriso et al. 2007, 2009, 2014). Inherently, crustose coralline algae that settled in the extremely low pH (mean pH 6.9), however, were significantly smaller and exhibited altered skeletal mineralogy (high Mg calcite to gypsum, hydrated calcium sulfate, Kamenos et al. 2016). In an undisturbed site where the $\mathrm{NO}_{3}$ and $\mathrm{NO}_{2}$ were lower and $\mathrm{Si}(\mathrm{OH})_{4}$ was higher, some species (Hydrolithon farinosum (J.V.Lamouroux) Penrose \& Y.M.Chamberlain, 1993, Fosleilla spp. and P. fragile) of epiphytic red algae were dominant (Mabrouk et al. 2013).

A species of the present study, Hydrolithon boreale (Foslie) Y.M.Chamberlain, 1994 is one of the larger specimens of the microcalcareous red algae in term of size of its crust (up to 2-5 mm in diameter; Reyes and Afonso-Carrillo 1995; Bradassi 2011), and has been reported here for the Turkish Mediterranean Sea. Researches on invasion success and mechanisms can guide scientists to understand regulation by a complex set of factors, including biotic and abiotic features of recipient systems, disturbance regimes, and invader life traits (Sol et al. 2012). Therefore, this brings the following present study. Regarding to the ecological importance of the calcareous seaweed in the marine environment and the historical lack of comprehensive information on their distribution and ecology in the Turkish waters, the aim of this study is to provide baseline information on bathymetric and seasonal distribution and biometrical patterns (density and plant traits) of the $H$. boreale recently appeared on the leaves of $P$. oceanica in the infralittoral of the Turkish pristine coast, a region of the most ultra-oligotrophic waters (Sisma-Ventura et al. 2017) of the Mediterranean Sea, and to determine biometrical dynamics and the species-environment relation of the biggest microcalcareous species emphasizing the siliciclastic-carbonate deposition. 


\section{Study area}

The study area was located in infralittoral zone regionally limited by a bottom depth of $30 \mathrm{~m}$ extending occasionally to 40-43 m hereby along the southern coast of Turkey (Mutlu et al. 2020a). The area was between Taşuçu Bay, Mersin through Antalya and Datça Bay, Muğla, along three provinces (Figure 1). The study area was restricted by Taşucu Bay in the eastern Turkish coast since there are no further locations of a meadow, $P$. oceanica beyond Taşucu Bay to eastern end of the eastern Mediterranean Sea (Ergün Taşkın who researches presence of the meadows and macrophytes by SCUBA, pers. comm.). The study area has a coastline length of about $1100 \mathrm{~km}$ (Figure 1a).

Eastern half of Mersin Bay is nutritionally fed by three major (Seyhan, Ceyhan and Göksu) rivers and partially under influence of the Nile River (Figure 1b). Owing to few brooks having moderate flow rate, Antalya Bay is oligotrophic compared to the Mersin Bay. Muğla's bays and coves are devoid of rivers and brooks but, partially fed with local creeks and have undergone the effect of the Aegean Sea from east to west (Figure 1).

Overall, sea surface temperature is at minima in December-February (14-17 to $21^{\circ} \mathrm{C}$ ), at maxima in July (19-28 $\left.{ }^{\circ} \mathrm{C}\right)$-August $\left(28-30\right.$, and to $\left.31^{\circ} \mathrm{C}\right)$, and decreased from eastern to western coasts of the present study area. Overall, the salinity varied seasonally between 38 and 39 PSU ( 40 PSU in August-early September) (Mutlu et al. 2020a).

The prevailing surface rim current of the Turkish Mediterranean coast was cyclonically circulated from İskenderun Bay (the easternmost Mediterranean Sea), flowed off Mersin Bay reaching Taşucu Bay, and crossed off Antalya Gulf (cape to cape, Figure 1f) then to Rhode Island where the current is bifurcated northerly and southerly (El-Geziry and Bryden 2010). The current velocity was faster than $20 \mathrm{~cm} \mathrm{~s}^{-1}$ typical for the entire Mediterranean Sea, but was generally about $50 \mathrm{~cm} \mathrm{~s}^{-1}$ on average along the Turkish Mediterranean coast (Poulain et al. 2013).

Anthropogenic effects were present with a variety of the sources as follows: Regarding to the marine litter presumably shading the canopy of the meadows has increased from east to west of the study area by the tourism, fishery and maritime activities (Gündoğdu and Çevik 2017; Olguner et al. 2018; Mutlu et al. 2020b) along the bottom gradient (Olguner et al. 2018; Mutlu et al. 2020b). Öztürk et al. (2021) studied anthropogenic effect of trace elements in Posidonia blades and its sediments in the present study area; the highest bioaccumulation factor in P. oceanica was calculated for $\mathrm{Cd}$. Coastal waters was heavily exposed to trace elements and significant positive correlations were detected between the anthropogenic trace element pollutants ( $\mathrm{As}, \mathrm{Cd}, \mathrm{Cu}, \mathrm{Zn}, \mathrm{Pb}$, and $\mathrm{V}$ ) and natural sourced trace element ( $\mathrm{Ni}$ and $\mathrm{Cr}$ ). The Mediterranean Sea coast of Turkey did not have significant levels of $\mathrm{Zd}, \mathrm{Cd}, \mathrm{Cu}$, and $\mathrm{Pb}$ pollution, whereas $65 \%$ of the stations were heavily polluted with As. The study area, particularly Muğla's coasts which have high angle of bottom trend has been visited by thousands of the pleasure crafts affecting the population of the meadows by their anchorages, especially in summer (Mutlu et al. 2020b). Furthermore, the study 
area is under influence of intensive coastal agricultural activities, particularly throughout the coast of Mersin and Antalya providences (Figure 1f).

There are three main rivers with high flow rates in the easternmost of the Turkish Mediterranean coasts, which influence coastal zone till Anamur Cape from the east by diluting the rate westward. There are many small scale brooks along the Antalya's coast, and some creeks along Muğla's coasts (Figure 1b). Springs of the streams were sourced through the Taurus mountain range parallel to the Turkish Mediterranean coast (Figure 1b). The study area has been influenced by the geological structure of the mountain. The geological chronology showed that the mountain had mixed siliciclastic-carbonate during the Palaeozoic, carbonate deposition during Jurassic-Cretaceous and then shallow-water carbonates inducing deeper-water deposits during Palaeocene-Eocene (Dumant et al. 2017). Therefore, the streams and groundwater feed and enhance the study area with the siliciclastic-carbonate and drains of anthropogenic sources around beds of the streams as well (Figure 1). The flow rates of the streams and groundwater have decreased in time due to climate change and global warming.

\section{Materials And Methods}

\section{Sample collection}

Collection of Posidonia oceanica samples was conducted in winter (December 2018/January 2019) and summer (June/July 2019) along the entire Turkish Mediterranean coast (Figure 1) since the biometrics of the meadows was at minima in winter and at maxima in summer. Referring to the echogram of the echosounder to see absences/presence of $P$. oceanica on the seafloor, 64 stations were sampled by a van Veen grab (ca. $0.1 \mathrm{~m}^{2}$ at 13 stations) and SCUBA ( $0.4 \times 0.4 \mathrm{~m}$ of a quadrate frame at 51 stations, and a total of 49 stations was inhabited by $P$. oceanica) in winter, and 112 stations ( 6 by a van Veen grab and 106 by SCUBA, and 103 by $P$. oceanica) in summer. The stations were triplicate-sampled.

Sampling bottom depth varied between $5 \mathrm{~m}$ and $50 \mathrm{~m}$ but generally between $10 \mathrm{~m}$ and $30 \mathrm{~m}$ at $5 \mathrm{~m}$ interval because of the safety of R/V "Akdeniz Su" with a draft of $3.7 \mathrm{~m}$ at the shallowest waters, sometimes extending to $35-40 \mathrm{~m}$. Each cruise lasted 1.5-2 months to complete the field work (Figure 1).

Furthermore, a study conducted by Mutlu et al. (2014) was involved into the present study to understand temporal trend of biometrics of another encrusting alga, $P$. fragile found on a seagrass, Cymodocea nodosa (Ucria) Ascherson collected at one location (a bottom depth of $15 \mathrm{~m}$ ) around an island of the present study area, visited in November 2011, January 2012, March, April, and August 2012 (marked by arrow in Figure 1c).

Some environmental parameters of water columns were measured and sampled from the surface (prefix $\mathrm{S}$ ) and near-bottom (prefix $\mathrm{N}$ ) waters of the stations on the board. These parameters were physical ( $\mathrm{T}$; temperature in ${ }^{\circ} \mathrm{C}, \mathrm{pH}$; $\mathrm{pH}, \mathrm{S}$; salinity in $\mathrm{PSU}$, and $\mathrm{O}$; oxygen in $\mathrm{mg} / \mathrm{l}$ ) using a multi-parameter probes ( $\mathrm{YSI}$, $\mathrm{HiTech}$ ), chemical (nutrients; $\mathrm{NO}_{2}+\mathrm{NO}_{3}, \mathrm{NH}_{4}$, and $\mathrm{PO}_{4}, \mathrm{SiO}_{2}$, chl $a$ and $\mathrm{TSM}$; total suspended matter). The oxygen was measured only in winter since the oxygen probe was malfunctioned in summer and the 
chemical parameters were sampled only in summer due to low occurrence of the epiphyte in winter (Figures 2-3). One litter of the water was filtered through $\mathrm{CF} / \mathrm{C}$ for each, of the nutrients, and total suspended matter and through $\mathrm{CF} / \mathrm{F}$ filters for chl $a$, and then all was kept at freezer having $-20{ }^{\circ} \mathrm{C}$ on board during the field survey.

\section{Bottom types}

Bottom types were determined since the type can differentiate the biometry of the meadows (Giovannetti et al., 2008; Sghaier et al., 2013; Maida et al., 2013; Montefalcone et al., 2016), hence distribution of the epiphyte. During the survey, SCUBA divers visually determined the bottom types and the grab as well. Harmonizing data obtained by SCUBA, and the grab, final bottom types were classified as pure white sand, sand, muddy sand, mud, mostly biogenic materials; molluscan fragment originated-gravel, rocks and matte (about $2 \mathrm{~m}$ high) of $P$. oceanica along the study area (Figure 1). White sand was kept distinguished from the gray sand and mud (mud) because presumably of different origin of the sand source and total organic carbon content in the sediment. Gravelly bottom was not encountered in summer survey.

\section{Sample studies}

Onboard, samples of the meadow were preserved in borax-buffered formaldehyde (3\%) in plastic jars on deck of the R/V “Akdeniz Su”.

In the laboratory, nutrients were measured following the standard procedures: Ammonium $\left(\mathrm{mg} \mathrm{NH}_{4} / \mathrm{l}\right)$, nitrate $\left(\mathrm{mg} \mathrm{NO}_{3} / \mathrm{l}\right)$, nitrite $\left(\mathrm{mg} \mathrm{NO}_{2} / \mathrm{l}\right)$, phosphate $\left(\mathrm{mg} \mathrm{PO}_{4} / \mathrm{l}\right)$, and silicon dioxide $\left(\mathrm{mg} \mathrm{SiO}_{2} / \mathrm{l}\right)$ were measured using the methods of $4500-\mathrm{NH}_{4} \mathrm{~B}, 4500 \mathrm{NO}_{3}-\mathrm{E}, 4500 \mathrm{NO}_{2}-\mathrm{B}, 4500-\mathrm{P} \mathrm{E}$, and 4500-SiO 2 Silica, respectively (APHA 1999). The values of the nutrients were converted of a unit $\mu \mathrm{M}$.

Total suspended solids (material was dried in an oven at $60{ }^{\circ} \mathrm{C}$ for $24 \mathrm{~h}$, and then weighed before the weight of the dried membrane was subtracted from the total dry weight), and chlorphyll a (chl-a) using a method described by Lorenzen (1967). Secchi disk depth was recorded once at each station.

A total of 45 and 100 stations were analyzed for the biometry of a calcareous epiphyte, $H$. boreale in winter and summer, respectively. A total of 2928 and 5028 shoots, and 11662 and 24509 leave of the meadows were measured for scanning the epiphyte in winter and summer, respectively. Of the epiphytes, $H$. boreale was majorly recorded on the leave of $P$. oceanica (Appendices 2-3), regardless of very tiny epiphytes at a scale of ultra/net size (Appendix 2). The leaves were generally clear of the other epiphyte owing to the study area being at oligotrophic level (Appendix 1). Crust diameter (D) and thickness (T, height of about cylindrical crust) of $H$. boreale were measured using an ocular micrometer scale under binocular microscope. All measurements were converted to $\mathrm{mm}$. The crust weight was estimated from the crust volume (cylinder) and density of calcium carbonate $\left(2.711 \mathrm{~kg} / \mathrm{m}^{3}\right)$. Abundance $\left(\mathrm{TN}, \mathrm{ind} / \mathrm{m}^{2}\right)$ and biomass $\left(B, \mu \mathrm{g} / \mathrm{m}^{2}\right)$ of $H$. boreale were calculated to be values per square meter. The biomass was 
estimated because it depended on the size and abundance together. Furthermore, one-sided Leaf Surface Area $\left(\mathrm{LAl}, \mathrm{m}^{2} / \mathrm{m}^{2}\right)$ of $P$. oceanica was calculated to relate to the biometry of the epiphyte.

\section{Statistical analyses}

Of the univariate analyses, Spearman rank correlation and partial correlation were subjected to data between biometry of the epiphyte and the environmental data to estimate the hidden environmental variables. The Spearman correlation was applied between trace elements $(\mathrm{mg} / \mathrm{kg})$ in blades of $P$. oceanica and its sediments (Öztürk et al. 2021), the biometrics of the epiphyte and LAI of $P$. oceanica to estimate effect of anthropogenic trace elements on the biometrics. The Generalized Additive Model (GAM) was used to estimate the effect of the predicted environmental parameters (all of physics, chemists and optics, and each of physics, and chemists separately) to the response biometrical variables of the epiphyte for summer survey. The univariate statistical analyses were performed using the statistical tools of the MatLab (vers. 2021a, Mathworks inc).

The following statistical analyses designed according to the results of the univariate statistical analyses. Of the multivariate analyses, the multiple regression was used to test the relationship and correlation between the biometrics of the epiphyte and LAl of $P$. oceanica \& concentration of sea surface $\mathrm{SiO}_{2}$ using the MatLab statistical tool. Principal Coordinate Analyses (PCO) was applied to a triangular Euclidean distance matrix of the biometry to figure out the best variable with the variation on the component and then the PCO configuration on the axes was correlated with the environmental variables using the Spearman rank correlation for summer survey. The multivariate analyses were performed using PRIMER 6 (vers. 6.1.13) + PERMANOVA + (1.0.3.).

\section{Results}

Understanding the biometrical dynamic of an encrusting red algae, $P$. fragile on a seagrass, $C$. nodosa in time, data of a previous unpublished study (Mutlu et al. 2014) were examined since they were sampled at five months a year (Figure 2). This guides at filling the gap of their temporal dynamic between winter and summer samplings conducted in the present study. The abundance and biomass increased slightly from January to April, and then peaked in August, followed by occurrence of decrement in November (Figure 2). The size was distributed in contrast to the temporal density of the epiphyte, and the LAI of $C$. nodosa did the same distribution as well (Figure 2). However, any individual of calcareous red algae on leave of $P$. oceanica in the Gulf of Antalya was not encountered during 2011-2012 (Mutlu et al. 2014). Coverage of P. fragile was $6.4 \%$ of leaf surface of $C$. nodosa on average and varied between $1.6 \%$ in March and $16.0 \%$ in August.

\section{Distribution of Hydrolithon boreale}

Hydrolithon boreale on leave of $P$. oceanica occurred at $25 \%$ of the total stations in winter, at $44 \%$ in summer during the present study (Figure 3 ). An average coverage of $H$. boreale was $0.12 \%$ (max: $0.75 \%$ ) 
of leaf surface of $P$. oceanica. Most occurrences took place along the westernmost coast of the study area, Muğla's coast in winter, and all coasts of three provinces in summer (Figures 3-4).

An average abundance of 41 and $49 \mathrm{ind} / \mathrm{m}^{2}$ on the study area (163 and $112 \mathrm{ind} / \mathrm{m}^{2}$ on stations where the epiphyte occurred) was estimated in winter and summer, respectively (Table 1 ). In winter, maximum abundance and biomass was recorded in a particular area of the Muğla's coast where there used to be fish farms in 2000s (c.a. 2000-2005). In summer, the abundance and biomass were maximized in the easternmost location opposed to the location in winter, and were highly variable with the regions along the coast of the study area (Figures 3-4). The lowest biomass and abundance occurred along the Antalya's coast with a few exceptions of the locations, and a moderate value was along the Muğla's coasts.

Diameter of $H$. boreale's crust was less in winter than that in winter on average, almost similar around 2.5$2.9 \mathrm{~mm}$ in all stations in winter while the diameter was very different in the regions of the study area (Table 1). The maximum diameter almost doubled the winter values in summer in contrast to the abundance and biomass in summer with exception of Antalya's Gulf where the meadows were found only on the rocks (Figures 1-4). This contrast seemed to be more pronounced on soft bottom (sand and mud) and dead matte in about $2 \mathrm{~m}$ high.

Similar to the diameter, thicker crust of $H$. boreale was observed in Muğla's coast in both winter and summer. This trend was more apparent in summer. The thickness was in similar range between winter and summer (Table 1).

Table 1 Average (Avg) and standard deviations (SD) of the biometrics of Hydrolithon boreale and LAl of Posidonia oceanica for all stations and the stations where Hydrolithon boreale was present in winter and summer.

\begin{tabular}{lllllllllll}
\multicolumn{3}{c}{ On all stations } & \multicolumn{1}{c}{ On only presence } \\
\hline & TN & D & T & B & LAl & TN & D & T & B \\
& ind $/ \mathrm{m}^{2}$ & $\mathrm{~mm}$ & $\mathrm{~mm}$ & $\mu \mathrm{g} / \mathrm{m}^{2}$ & & ind $/ \mathrm{m}^{2}$ & $\mathrm{~mm}$ & $\mathrm{~mm}$ & $\boldsymbol{\mu g} / \mathbf{m}^{2}$ \\
\hline Avg & 41 & 0.57 & 0.074 & 0.171 & 1.48 & 163 & 2.23 & 0.290 & 0.671 \\
\hline SD & 134 & 0.99 & 0.128 & 0.528 & 0.95 & 231 & 0.30 & 0.022 & 0.895 \\
\hline Avg & 49 & 1.11 & 0.131 & 0.232 & 3.11 & 112 & 2.52 & 0.297 & 0.529 \\
\hline SD & 136 & 1.34 & 0.148 & 0.618 & 2.18 & 188 & 0.70 & 0.017 & 0.847
\end{tabular}

Of the environmental parameters, sea surface $\mathrm{SiO}_{2}$ concentration was however straight-proportionally overlapped on the size of the epiphyte, but reversely on the density (abundance and biomass) depending 
on the size of epiphyte and LAI of P. oceanica in summer (Figure 3). The larger epiphyte carried the less abundance on a given LAl.

\section{Epiphyteenvironment relation}

Biometrics of the epiphyte was correlated negatively with sea surface temperature, and positively dissolved oxygen concentrations of the near-bottom water in winter at $p<0.05$. However, there was a significant correlation between the biometrics and bottom type (Table 2). Sea surface temperature was negatively correlated with the diameter and oxygen positively with density variables of the epiphyte in winter.

Table 2 Spearman correlation between the biometrics of epiphyte and physical environmental parameters (see Table 6 for the abbreviations), and bottom depth (De) and type (BT) in winter. The bold values are significantly correlated at $p<0.05$.

\begin{tabular}{|c|c|c|c|c|c|c|c|c|}
\hline & TN & & D & & $\mathrm{T}$ & & B & \\
\hline & $r$ & $p$ & $r$ & $p$ & $r$ & $p$ & $r$ & $p$ \\
\hline SS & -0.211 & 0.155 & -0.188 & 0.205 & -0.156 & 0.295 & -0.213 & 0.151 \\
\hline ST & -0.279 & 0.057 & -0.309 & 0.035 & -0.267 & 0.069 & -0.279 & 0.058 \\
\hline SpH & 0.129 & 0.388 & 0.101 & 0.498 & 0.12 & 0.42 & 0.126 & 0.399 \\
\hline so & 0.303 & 0.038 & 0.278 & 0.059 & 0.281 & 0.056 & 0.302 & 0.039 \\
\hline NS & 0.057 & 0.702 & 0.038 & 0.802 & 0.062 & 0.678 & 0.058 & 0.698 \\
\hline NT & -0.29 & 0.048 & -0.305 & 0.037 & -0.298 & 0.042 & -0.29 & 0.048 \\
\hline $\mathrm{NpH}$ & -0.047 & 0.755 & -0.065 & 0.664 & -0.065 & 0.666 & -0.052 & 0.726 \\
\hline NO & 0.301 & 0.04 & 0.313 & 0.032 & 0.292 & 0.047 & 0.3 & 0.04 \\
\hline $\mathrm{Sec}$ & 0.13 & 0.383 & 0.136 & 0.363 & 0.164 & 0.272 & 0.133 & 0.374 \\
\hline De & -0.119 & 0.427 & -0.103 & 0.489 & -0.117 & 0.434 & -0.121 & 0.419 \\
\hline BT & 0.4216 & 0.0032 & 0.3431 & 0.0182 & 0.3643 & 0.0118 & 0.4206 & 0.0032 \\
\hline
\end{tabular}

In summer, near-bottom temperature correlated positive-significantly the density variables (abundance and biomass) of the epiphytes in contrast to that in winter. Interestingly, the biometrics was negativesignificantly correlated with sea surface concentration of the $\mathrm{SiO}_{2}$, but positively with salinity of the nearbottom water (Table 3). The $\mathrm{PO}_{4}$ of the near-bottom water was positively correlated with only crust diameter at $p<0.05$ (Table 3). 
Table 3 Spearman correlation between the biometrics of epiphyte and physical and chemical environmental parameters (see Table 6 for the abbreviations), and bottom depth (De) and type (BT) in summer. The bold values are significantly correlated at $p<0.05$. 
TN

D T

B

\begin{tabular}{|c|c|c|c|c|c|c|c|c|}
\hline & $r$ & $p$ & $r$ & $p$ & $r$ & $p$ & $r$ & $p$ \\
\hline SS & -0.081 & 0.424 & -0.113 & 0.262 & -0.108 & 0.284 & -0.096 & 0.344 \\
\hline ST & 0.049 & 0.626 & -0.098 & 0.33 & -0.011 & 0.915 & 0.046 & 0.653 \\
\hline SpH & 0.106 & 0.295 & 0.038 & 0.704 & 0.079 & 0.437 & 0.107 & 0.289 \\
\hline NS & 0.29 & 0.003 & 0.358 & 0 & 0.318 & 0.001 & 0.283 & 0.004 \\
\hline NT & 0.235 & 0.019 & 0.151 & 0.134 & 0.188 & 0.061 & 0.237 & 0.018 \\
\hline $\mathrm{NpH}$ & -0.043 & 0.672 & -0.059 & 0.558 & -0.017 & 0.87 & -0.029 & 0.771 \\
\hline $\mathrm{Sec}$ & -0.156 & 0.12 & -0.08 & 0.428 & -0.096 & 0.341 & -0.144 & 0.153 \\
\hline De & -0.146 & 0.146 & -0.18 & 0.073 & -0.156 & 0.122 & -0.169 & 0.093 \\
\hline BT & -0.0114 & 0.91 & 0.1476 & 0.1428 & 0.0614 & 0.5437 & -0.0097 & 0.9239 \\
\hline Ssi & -0.342 & 0.000 & -0.309 & 0.002 & -0.287 & 0.004 & -0.321 & 0.001 \\
\hline $\mathrm{SNO}_{3}$ & -0.075 & 0.459 & -0.074 & 0.463 & -0.026 & 0.794 & -0.059 & 0.560 \\
\hline $\mathrm{SPO}_{4}$ & 0.020 & 0.841 & -0.002 & 0.981 & -0.022 & 0.831 & 0.011 & 0.912 \\
\hline $\mathrm{SNO}_{2}$ & -0.006 & 0.955 & 0.040 & 0.690 & 0.064 & 0.525 & 0.004 & 0.966 \\
\hline $\mathrm{SNH}_{4}$ & -0.108 & 0.283 & -0.088 & 0.383 & -0.081 & 0.423 & -0.111 & 0.270 \\
\hline $\mathrm{SNO}_{2}+\mathrm{NO}_{3}$ & -0.036 & 0.722 & 0.009 & 0.925 & 0.035 & 0.728 & -0.023 & 0.817 \\
\hline Nsi & -0.061 & 0.545 & 0.054 & 0.594 & 0.031 & 0.759 & -0.050 & 0.623 \\
\hline $\mathrm{NNO}_{3}$ & -0.130 & 0.196 & -0.051 & 0.618 & -0.116 & 0.249 & -0.123 & 0.223 \\
\hline $\mathrm{NPO}_{4}$ & 0.152 & 0.131 & 0.212 & 0.034 & 0.148 & 0.143 & 0.150 & 0.136 \\
\hline $\mathrm{NNO}_{2}$ & 0.079 & 0.433 & 0.091 & 0.367 & 0.124 & 0.218 & 0.085 & 0.403 \\
\hline $\mathrm{NNH}_{4}$ & 0.042 & 0.679 & 0.086 & 0.395 & 0.095 & 0.347 & 0.043 & 0.673 \\
\hline $\mathrm{NNO}_{2}+\mathrm{NO}_{3}$ & 0.043 & 0.673 & 0.054 & 0.592 & 0.084 & 0.403 & 0.047 & 0.640 \\
\hline STSM & -0.170 & 0.091 & -0.127 & 0.208 & -0.116 & 0.252 & -0.172 & 0.087 \\
\hline NTSM & -0.083 & 0.412 & -0.146 & 0.148 & -0.195 & 0.052 & -0.088 & 0.385 \\
\hline Chl a & -0.147 & 0.146 & -0.135 & 0.182 & -0.094 & 0.352 & -0.145 & 0.150 \\
\hline
\end{tabular}


There was an obvious relationship between density and diameter of the epiphyte and the sea surface silicate $\left(\mathrm{SiO}_{2}\right)$ and LAl of the meadow in summer (Figure 4). However, biometrics of the epiphyte was not significantly correlated with the LAl of $P$. oceanica at $p<0.05$, which has brought about the multipleregression between the variables aforementioned.

Statistics of the linear multiple-regression was given in Table 4 for the relationship between biometrics of the epiphyte and the sea surface silicate $\left(\mathrm{SiO}_{2}\right)$ and LAl of the meadow in summer. To extract out the hidden variables of the $\mathrm{LAl}$ and $\mathrm{SiO}_{2}$ in linear relation to the biometrics, Spearman partial correlations showed that none of the variables was correlated with the biometrics at $p<0.05$. Multiple-linear regression showed that there was however a significant correlation only between the thickness and the $\mathrm{LAl}$ and $\mathrm{SiO}_{2}$ at $\mathrm{p}<0.05$ in Table 4. Regarding to the $b$ value, the LAl affected biometrics positively, but the $\mathrm{SiO}_{2}$ negatively (Table 4).

Table 4 Linear multiple-regression constants ( $a$; intercept, $b$; slope) between the biometrics of epiphyte and LAl of Posidonia oceanica and sea surface $\mathrm{SiO}_{2}$ in summer. Bold $a$ and $b$ values were significantly represented for the relationship and $p$ value was significantly correlated $\left(R^{2}\right)$ for the multiple correlation at $\mathrm{p}<0.05$.

\begin{tabular}{llllll} 
& $\boldsymbol{a}$ & $\boldsymbol{b}(\mathrm{LAl})$ & $\boldsymbol{b}\left(\mathrm{SiO}_{2}\right)$ & Adjusted $\boldsymbol{R}^{2}$ & $\boldsymbol{p}$ \\
\hline $\mathrm{TN}$ & $\mathbf{6 3 . 8 6 3}$ & 2.629 & -5.526 & 0.01 & 0.228 \\
\hline $\mathrm{D}$ & $\mathbf{1 . 4 4 7}$ & -0.013 & $-\mathbf{0 . 0 7 1}$ & 0.03 & 0.091 \\
\hline $\mathrm{T}$ & $\mathbf{0 . 1 7 0}$ & 0.0005 & $-\mathbf{0 . 0 1 0}$ & 0.06 & $\mathbf{0 . 0 2 1}$ \\
\hline $\mathrm{B}$ & $\mathbf{0 . 3 0 4}$ & 0.011 & -0.025 & 0.01 & 0.227
\end{tabular}

Based on all environmental variables, the abundance of the epiphyte was not partial-correlated with any of the environmental parameters. The nutrients were not partial-correlated with any of the biometrics (Table 5). Diameter, thickness and biomass were positively partial-correlated with six of the environmental parameters at $p<0.05$ (Table 5). The LAl of $P$. oceanica was highly correlated with the biometrics of the epiphyte (Table 5).

Table 5 Partial correlation coefficients between biometrics and the environmental parameters (see Table 6 for the abbreviations) for summer samplings. Values are only correlation coefficients which were significantly partial-correlated at $p<0.05$. 


\begin{tabular}{llll} 
& D & T & B \\
\hline SpH & 0.206 & 0.243 & 0.235 \\
\hline NS & 0.229 & 0.218 & 0.200 \\
\hline NpH & 0.211 & 0.253 & 0.246 \\
\hline STSM & 0.302 & 0.335 & 0.327 \\
\hline NTSM & 0.299 & 0.335 & 0.328 \\
\hline Chl $a$ & 0.282 & 0.320 & 0.309 \\
\hline LAl & 0.920 & 0.929 & 0.928
\end{tabular}

The Generalized Additive Model (GAM) performed with all environmental parameters in summer showed that abundance (TN) of the epiphyte was positively affected first with sea surface temperature (ST), followed by the $\mathrm{SpH}$, and total suspended matter (TSM) in negative way (Figure 5). The crust diameter (D) was negatively affected by the ST, and positively by the bottom depth. The biomass (B) including also contribution of crust thickness $(T)$ was influenced with more variables compared to abundance and diameter; the $\mathrm{SpH}$ and $\mathrm{NpH}$ affected negatively and positively the biomass, respectively. These variables were followed by the $\mathrm{SNH}_{4}$ under positive influence, and the SS and NTSM under negative influence related to the biomass (Figure 5).

Eliminating this complexity derived from the effects of all the environmental variables on the biometrics, the GAM was solved for effectiveness of each of physical and chemical variables separately (Figures 67).

With respect to only physical environmental parameters, the abundance was positively affected by the ST, followed negatively by the SS and slightly Sec. The diameter and thickness were mostly influenced by the $\mathrm{pH}$ and $\mathrm{S}$; the $\mathrm{pH}$ affected positively the size and biomass as a function of the diameter and thickness, but the salinity negatively did (Figure 6).

In terms of effect of only chemical parameters, the TN was under negative effect of the NTSM and $\mathrm{NNO}_{3}$, and followed by that under positive effect of the $\mathrm{SPO}_{4}$ and $\mathrm{SSi}$. Overall, $\mathrm{N}$-based nutrients affected negatively the abundance (Figure 7). The $\mathrm{NNO}_{2}+\mathrm{NO}_{3}, \mathrm{SSi}$ and $\mathrm{NNO}_{2}$ increased the diameter of epiphyte, and the size was reduced by the $\mathrm{NNO}_{3}$ and $\mathrm{SNO}_{2}$ (Figure 7). As occurred in the abundance, NTSM decreased the biomass, but the $\mathrm{SSi}$ and $\mathrm{SNH}_{4}$ increased the biomass of the epiphyte (Figure 7).

Significant part (97.5\%) of the total explained variance occurred on the PCO1 to estimate the first component based and launched on the biometrics well-correlated with SSi (Table 6 and Figure 8). The density (B and TN) of the epiphyte increased with the NS and ST, and decreased with the SSi (Table 6 and 
Figure $8 a, b, d)$. The distribution of the crust diameter (D) was exactly contrasted to the density of the epiphytes on the PCO (Figure 8a-c).

Table 6 Spearman correlation coefficients between the environmental parameters and the PCO solution of the biometrics.

\begin{tabular}{|c|c|c|c|}
\hline Environmental variables & Abbreviations & PCO1 & $\mathrm{PCO} 2$ \\
\hline Sea surface salinity (PSU) & SS & 0.084 & 0.102 \\
\hline Sea surface temperature $\left({ }^{\circ} \mathrm{C}\right)$ & ST & -0.041 & 0.177 \\
\hline Sea surface $\mathrm{pH}$ & $\mathrm{SpH}$ & -0.103 & 0.101 \\
\hline Near-bottom water salinity (PSU) & NS & -0.289 & -0.237 \\
\hline Near-bottom water pH & $\mathrm{NpH}$ & 0.044 & 0.038 \\
\hline Near-bottom water temperature $\left({ }^{\circ} \mathrm{C}\right)$ & NT & -0.124 & -0.127 \\
\hline Secchi disk depth $(\mathrm{m})$ & $\mathrm{Sec}$ & 0.152 & -0.080 \\
\hline Bottom depth (m) & De & 0.148 & 0.062 \\
\hline Sea surface $\mathrm{SiO}_{2}(\mu \mathrm{M})$ & Ssi & 0.342 & 0.105 \\
\hline Sea surface $\mathrm{PO}_{4}(\mu \mathrm{M})$ & $\mathrm{SPO}_{4}$ & -0.019 & -0.075 \\
\hline Sea surface $\mathrm{NH}_{4}(\mu \mathrm{M})$ & $\mathrm{SNH}_{4}$ & 0.111 & 0.032 \\
\hline Sea surface $\mathrm{NO}_{2}+\mathrm{NO}_{3}(\mu \mathrm{M})$ & $\mathrm{SNO}_{2}+\mathrm{NO}_{3}$ & 0.037 & -0.078 \\
\hline Near-bottom water $\mathrm{SiO}_{2}(\mu \mathrm{M})$ & Nsi & 0.061 & -0.192 \\
\hline Near-bottom water $\mathrm{PO}_{4}(\mu \mathrm{M})$ & $\mathrm{NPO}_{4}$ & -0.157 & -0.094 \\
\hline Near-bottom water $\mathrm{NH}_{4}(\mu \mathrm{M})$ & $\mathrm{NNH}_{4}$ & -0.042 & 0.039 \\
\hline Near-bottom water $\mathrm{NO}_{2}+\mathrm{NO}_{3}(\mu \mathrm{M})$ & $\mathrm{NNO}_{2}+\mathrm{NO}_{3}$ & -0.045 & -0.011 \\
\hline Sea surface total suspended matter $(\mathrm{mg} / \mathrm{l})$ & STSM & 0.170 & -0.119 \\
\hline Near-bottom water total suspended matter (mg/l) & NTSM & 0.086 & 0.117 \\
\hline Sea surface chlorophyll a (mg/l) & $\mathrm{Chl} \mathrm{a}$ & 0.148 & -0.070 \\
\hline
\end{tabular}

The best descriptive trait of the biometric in direct correlation with the SSi was the diameter of the epiphyte (Figure 8c, d) since the other biometrics changed dependently on LAl of its host, $P$. oceanica and thickness. The enlargement of the diameter was accelerated after a threshold of about $80 \mu \mathrm{M}$ of the SSi 
to about $210 \mu \mathrm{M}$ which inhibited occurrence of the epiphyte (Figure $8 \mathrm{c}, \mathrm{d}^{*}$ ). This threshold could be due to action as limiting factor for $\mathrm{SiO}_{2}$ on the growth of the epiphyte.

Of the trace elements on the blades of the meadow, the Ni originated by the nature was negatively correlated with the crust biometrics of the epiphyte and LAI of $P$. oceanica at $p<0.05$ (Table 7). Of the anthropogenic-sourced trace elements $(\mathrm{V}, \mathrm{Cu}, \mathrm{Zn}, \mathrm{As}, \mathrm{Cd}$, and $\mathrm{Pb})$ in the blades, $\mathrm{Zn}$ was negatively correlated with only diameter of the epiphyte. In the sediments, the Ni affected negatively with the TN, T, and B of the epiphyte. However, the LAI was positively correlated with all the anthropogenic-sourced trace elements. The As was positively correlated with diameter of the crust (Table 7).

Table 7 Spearman correlation coefficients between the trace elements in blades of Posidonia oceanica and its sediments, and the biometrics of the epiphyte and LAl of $P$. oceanica in summer. Bold coefficients are significant at $p<0.05$.

\begin{tabular}{lllllllll} 
& $\mathbf{V}$ & $\mathbf{C r}$ & $\mathbf{N i}$ & $\mathbf{C u}$ & $\mathrm{Zn}$ & $\mathrm{As}$ & $\mathrm{Cd}$ & $\mathrm{Pb}$ \\
\hline TN & -0.051 & -0.076 & $-\mathbf{0 . 3 1 8}$ & -0.197 & -0.167 & 0.080 & -0.065 & 0.006 \\
\hline $\mathrm{D}$ & -0.154 & -0.143 & $-\mathbf{0 . 3 3 8}$ & -0.281 & -0.302 & 0.003 & -0.170 & -0.016 \\
\hline T & -0.092 & -0.092 & $-\mathbf{0 . 3 5 9}$ & -0.228 & -0.210 & 0.056 & -0.099 & 0.041 \\
\hline $\mathrm{B}$ & -0.041 & -0.065 & $-\mathbf{0 . 3 1 7}$ & -0.187 & -0.162 & 0.090 & -0.057 & 0.027 \\
\hline LAl & -0.045 & -0.076 & $-\mathbf{0 . 3 2 6}$ & -0.168 & -0.205 & -0.177 & -0.081 & -0.052 \\
\hline TN & 0.092 & -0.184 & $-\mathbf{0 . 4 1 8}$ & -0.026 & 0.020 & 0.237 & 0.149 & 0.018 \\
\hline $\mathrm{D}$ & 0.211 & 0.031 & -0.199 & 0.084 & 0.101 & $\mathbf{0 . 3 5 0}$ & 0.279 & 0.197 \\
\hline T & 0.179 & -0.087 & $-\mathbf{0 . 3 2 2}$ & 0.060 & 0.088 & 0.292 & 0.240 & 0.094 \\
\hline B & 0.101 & -0.176 & $-\mathbf{0 . 4 0 5}$ & -0.020 & 0.024 & 0.232 & 0.165 & 0.035 \\
\hline LAl & $\mathbf{0 . 4 6 3}$ & 0.110 & -0.171 & $\mathbf{0 . 3 6 1}$ & $\mathbf{0 . 4 2 9}$ & $\mathbf{0 . 3 8 4}$ & $\mathbf{0 . 4 0 1}$ & $\mathbf{0 . 3 5 8}$
\end{tabular}

\section{Discussion}

Of the epiphytes on $P$. oceanica, encrusting algae were significantly different in their distribution between leaves and rhizomes of $P$. oceanica, and species belonging to genus Pneophyllum and Hydrolithon spp were found generally on the leaves (Nesti et al. 2009). The epiphytic assemblages were indicators of various types of natural and anthropogenic disturbances, and occurred to grow detecting the moderate nutrient level (Balata et al. 2008). Hydrolithon spp and $P$. fragile are sensitive species for undisturbed areas (Sfriso et al. 2007, 2009).

Similar to our estimates in summer 2-3 fold higher than in winter, Sfriso et al. (2020) estimated an occurrence of $41.6 \%$ of a total of 107 stations for microcalcareous epiphytic seaweeds composed 
majorly of Hydrolithon, Pneophyllum and Melobesia species which had a thickness of few microns and a diameter of $50-200 \mu \mathrm{m}$ of their germinative discs in the Italian coasts. There was a relation of the epiphytic community to leaf age and size of seagrass (Reyes et al. 1998; Prado et al. 2008). Encrusting (generally belonging to the genera Hydrolithon and Pneophyllum) dominate the epiphytic communities occur as patches of crusts up to $3.5 \mathrm{~mm}$ in diameter, which vary in thickness between thin, monostromatic crusts several tens of microns thick (Beavington-PenneySimon et al. 2004). Crust size of H. boreale was up to 2-5 mm in diameter and up to $0.02 \mathrm{~mm}$ thick (Bradassi 2011; Reyes and AfonsoCarrillo 1995). Hydrolithon crusts were up to $2 \mathrm{~mm}$ in diameter and Pneophyllum fragile crusts up to 700 $\mu \mathrm{m}$ in diameter (Kjøsterud 1997). Hydrolithon farinosum (Lamouroux) comb. nov. up to $150 \mu \mathrm{m}$ thick (Penrose and Chamberlain 1993). Our measurements fell within above range of the crust size of the epiphyte.

Average leaf coverage on $P$. oceanica was estimated more than $1 \%$ by the encrusting coralline algae comprising mostly of $H$. farinosum and Pneophyllum spp (Prado et al. 2007) higher than our estimates (< $1 \%$ on average). The epiphyte, $H$. boreale was not found on blades of $P$. oceanica during 2011-2012 in Antalya Gulf, but $P$. fragile was determined on leaves of $C$. nodosa in an isolated island within the study area. The crust of $P$. fragile was grown up to $2 \mathrm{~mm}$ in diameter (Bradassi 2011) smaller than that of $H$. boreale (5 mm; Reyes and Afonso-Carrillo 1995). Therefore, C. nodosa had LAl enough only for Pneophyllum fragile considering the leaf width of $C$. nodosa. The $\mathrm{N}$-based nutrient concentrations decreased significantly from 2011-2012 (Mutlu et al. 2014) to 2019 in the Antalya Gulf contrasted to the P-nutrient (Appendix 4). The highest occurrence of the epiphyte was recorded in summer as stated for a difference in their dominance between winter and summer (Peterson et al. 2007). On contrary, richness of rhodophyta epiphytic algae was high in winter and low in spring-autumn around Canary Island where $P$. fragile and $H$. farinosum were permanent species on leave of $C$. nodosa (Reyes and Sanson 1997) and in the western Mediterranean Sea (Jacquemart and Demoulin 2008). Filamentous and crustose macroalgae were abundant in summer whereas crustose ( $P$. fragile and $H$. farinosum var. farinosum) were dominant in winter (Nesti et al. 2009; Tsirika et al. 2007). Red algae epiphytes on the rhizome was dominant in winter (Mabrouk et al. 2014), but $H$. farinosum and P. fragile on the in summer (Mabrouk et al. 2015). Since the leaf biomass was the highest in summer, the epiphyte biomass and coverage increased from April to August (Mabrouk et al. 2017).

With respect to the depthwise distribution of crustose macroalgae, their coverage decreased from the shallowest to the deepest station during both winter and summer (Tsirika et al. 2007). As the depth increased, increased diameter of the epiphyte limited increase in the density of epiphyte in a given LAl of $P$. oceanica in a matter of carrying capacity of the leaf during the present study.

Bottom types significantly affected the biometrics of the epiphyte only in winter. De Battisti et al. (2021) found no significant difference in the coverage of encrusting epiphytes on-between two sides of leaf, but bottom types significantly changed the coverage having higher on rocks than sand as occurred in the present study in function of the density of the epiphyte for the coverage (Appendix 5). However, Casola et al. (1987) underlined the preferences of the corollaceous epiphyte establishment on different parts and 
age of the leaves; The structure of the community changed along an age gradient that extended from the inner to the outer leaves and from the basis to the apex of each leaf; Fosliella - Pneophyllum spp. first colonized the leaf edges and then gradually covered the whole leaf surface near the tips (Casola et al. 1987).

Sensitive epiphytes were positively correlated with water transparency and the \%DO and the angiosperms and sensitive macroalgae as well (Bermejo et al. 2016), and with the salinity (Sfriso et al. 2017). Nevertheless, the nutrient concentrations in both water column and surface sediments and Chl-a were negatively correlated with the sensitive taxa (Sfriso et al. 2017).

The epiphyte was affected by the $\mathrm{pH}$ of the water. Sfriso et al. (2020) fixed a range of $\mathrm{pH}$ from $>7.93$ (Martin et al. 2008; Cox et al. 2015) to 8.35 for occurrence of the calcareous seaweeds. The higher pH inhibited utilization of $\mathrm{HCO}_{3}$ via $\mathrm{CO}_{2}$ to precipitate $\mathrm{CaCO}_{3}$ (Fragoso et al. 2010) in their tissues in the form of calcite deposited throughout the cell walls or aragonite (Mann 2001) for growth of calcareous seaweeds in the Mediterranean Sea (Sfriso et al. 2020). Furthermore, Hydrolithon and Pneophyllum spp had the highest coverage (18-69\%; Martin et al. 2008) on seagrass at a water pH of 8.1 (8.0-8.2) while there were no such epiphytes at $7.7 \mathrm{pH}$ (Martin et al. 2008; Mutalipassi et al. 2020) owing to a positive correlation between the coralline cover and epiphytic $\mathrm{CaCO}_{3}$ and $\mathrm{pH}$ (Martin et al. 2008). In the Mediterranean Sea, overall the decomposition of thionitrophilous taxa reduced $\mathrm{pH}$ values which slowed down the growth of small calcareous species such as $P$. fragile and Hydrolithon spp which cannot grow in poor-bad conditions (Sfriso et al. 2007, 2009, 2014).

Regarding to the essential nutrient concentrations, especially N-components to the marine flora, the nutrients had concentrations 2-3 fold more in 2011-2012 than those in 2019 (Appendix 4). The microcalcareous epiphytic seaweeds reappeared in a location classified as the bad ecological conditions and status which were then recovered to healthy conditions (Sfriso et al. 2020). High N-based (particularly $\mathrm{NO}_{3}$ ) nutrientphilic epiphytes produced the high biomass contrasted to moderate nutrientphilic epiphytes assigned as sensitive species (Balata et al. 2008). In summer, the epiphytes were increased on seagrass owing to low-concentration of the nutrient induced by the leaf turnover of the seagrass which was minima in winter (Peterson et al. 2007). This brought about a difference of $20 \%$ in the occurrence of epiphyte between winter and summer (Peterson et al. 2007) similar to the difference estimated in the present study.

On the leaves of the seagrass, biomass and number of epiphytic species were high at agricultural drainage, but was low at the references sites in regard to the different nutrient levels and LAl of the seagrass as well (Prado 2018). Nevertheless, Mabrouk et al. (2013) compared qualification and quantification of the epiphytes between the control where the water transparency and $\mathrm{NH}_{4}$ were relatively higher, and disturbed sites where the $\mathrm{NO}_{3}$ and $\mathrm{NO}_{2}$ were lower and $\mathrm{Si}(\mathrm{OH})_{4}$ was higher (reverse statements in the text regarding to Table 1 in Mabrouk et al. 2013); epiphytic red algae especially coralline algae as $H$. farinosum, Fosleilla spp. and $P$. fragile, were dominant in the disturbed area in contrast to the green epiphytic algae (Mabrouk et al. 2013) as agreed by the other studies (Lepoint et al. 
2007; Ben Brahim et al. 2010; Balata et al. 2010). Such epiphytes had tolerance to low light intensity, mostly shaded area (Boudouresque et al. 1984), and rapid absorption of nutrients (Lepoint et al. 2007). Indeed, they are very sensitive to the disturbance (Ben Brahim et al. 2010; Piazzi et al. 2002).

Besides the nutrients effects, the trace element concentrations ( $\mathrm{As}, \mathrm{Cd}, \mathrm{Cr}, \mathrm{Cu}, \mathrm{Ni}$ and $\mathrm{Pb}$ ) differentiated the density (shoot and LAI) of $P$. oceanica and epiphyte biomass in which Rhodophyta, mostly $P$. fragile and $H$. farinosum were predominated; the higher concentration of the trace elements caused the lower density and biomass (Bedini and Piazzi 2012) on contrasted to anthropogenic-sourced trace elements increasing density of $P$. oceanica, and of the natural trace elements, Ni decreasing the density and size of the epiphyte in the present study area undisturbed by the trace elements (Öztürk et al. 2021). Such epiphytes are classified as good ecological indicators based on the elements (Martinez-Crego et al. 2010). However, leaf epiphytes are known to be less sensitive to chemical impacts (Piazzi et al. 2004).

Inorganic carbon and carbonates were utilized by the microcalcareous epiphytic seaweed on the leaves of aquatic angiosperms (Sfriso et al. 2020). Inherently, crustose coralline algae that settled in the extremely low pH (mean pH 6.9), however, were significantly smaller and exhibited altered skeletal mineralogy (high Mg calcite to gypsum, hydrated calcium sulfate, Kamenos et al. 2016). The $\mathrm{SiO}_{2}$ was initially originated by the allochthonous sources from the land trough the streams to the marine environments and autochthonous through biogeochemical cycle in the water column and sediments derived from the silicate marine organisms such as diatoms. All applied statistical analyses showed that there were significant correlations between $\mathrm{SiO}_{2}$ concentration and biometrics of the epiphyte; decreasing the density and increasing size of the epiphyte on leaves of $P$. oceanica in such pristine coast of the present study. The study area was surrounded with the streams initialized from the high altitudes of the Taurus mountain range. The geological chronology showed that the mountain had mixed siliciclasticcarbonate, carbonate deposition and then deeper-water deposits derived from the shallow-water carbonates in the easternmost (e.g. Duman et al. 2017), centre (Ediger et al. 1997) shelf of the Turkish Mediterranean coast. Together with the $\mathrm{SiO}_{2}$, the streams can bring the carbonates (Walsh-Kennedy et al. 2014; Radeff et al. 2017), required for the epiphyte growth, into the study area. In an undisturbed site where the $\mathrm{NO}_{3}$ and $\mathrm{NO}_{2}$ were lower and $\mathrm{Si}(\mathrm{OH})_{4}$ was higher, some species (H. farinosum, Fosleilla spp. and $P$. fragile) of epiphytic red algae were dominant (Mabrouk et al. 2013). The total carbonate content $\left(\mathrm{CaCO}_{3}\right)$ of the sediment in Antalya Gulf varied between $30 \%$ and $80 \%$ in both winter and summer (Appendix 6, from Mutlu et al. 2014). The highest carbonate contents were measured around locations where the calcite rock was found. Finike Bay P. oceanica did not inhabit had low the carbonate content about $15 \%$ compared to the Antalya Gulf. The total carbonate then increased toward the west of the study area in summer (Appendix 6).

\section{Conclusion}

One of the sensitive species to the environmental disturbance, $H$. boreale was recently dominant on the blades of a Mediterranean meadow, P. oceanica along the entire Turkish Mediterranean coast. Crusts of 
$P$. fragile on leaves of $C$. nodosa grew up to $2.7 \mathrm{~mm}$ in diameter whilst crust of $H$. boreale on leaves of $P$. oceanica up to $2.9 \mathrm{~mm}$ in winter and $4.96 \mathrm{~mm}$ in summer. Later epiphytic species on leaves of the meadow were not observed in 2011-2012 in a large gulf of the present study area due to the high nutrient input available to the coast. The significantly reduced nutrients in the water stimulated the epiphyte to appear abundantly on the leaves in winter and summer 2019. An average coverage of $H$. boreale was $0.12 \%$ (max: $0.75 \%$ ) of leaf surface of $P$. oceanica. De Battisti et al. (2021) found no significant difference in the coverage of encrusting epiphytes on-between two sides of leaf. Most occurrences took place along the westernmost coast of the study area, Muğla's coast in winter, and all coasts of three provinces (Muğla-Antalya-Mersin) in summer. The size and density (abundance and biomass) of the epiphyte were contrasted depending on space on the leave surface. As an indication of the siliciclastic-carbonate deposition through the rivers from the Taurus mountain range located along the entire coast, primarily $\mathrm{SiO}_{2}$ (generally land sourced) of the water accelerated the size of epiphyte but reduced the density of the epiphyte. Such calcareous epiphytes are required for the growth of their crusts, mostly negatively affected with $\mathrm{pH}$ of the water as occurred in the present study. In such oligotrophic coast of the present study, the nutrients, especially $\mathrm{N}$-based nutrient $\left(\mathrm{NO}_{2}+\mathrm{NO}_{3}\right)$ was positively correlated with the size of the epiphyte. The nutrient concentrations in both water column and surface sediments and Chl-a were negatively correlated with the sensitive taxa (Sfriso et al. 2017). Following the environmental parameters, water turbidity (total suspended matter of the near-bottom water) and salinity affected negatively the size inhibiting the light intensity required for the epiphytic specimens. Sensitive epiphytes were positively correlated with water transparency and the \%DO and the angiosperms and sensitive macroalgae as well (Bermejo et al. 2016), and with the salinity (Sfriso et al. 2017). A naturally sourced trace element, $\mathrm{Ni}$ in blades of $P$. oceanica and its sediments was negatively correlated with the biometry of the epiphyte. However, anthropogenically sourced elements ( $\mathrm{V}, \mathrm{Cu}, \mathrm{Zn}, \mathrm{As}, \mathrm{Cd}$, and $\mathrm{Pb}$ ) caused increase in the leaf area surface (LAl) of the meadow whereas there were not any significant correlations between the contents of $\mathrm{Ni}$ and $\mathrm{Cr}$ (naturally sourced elements) and the LAl in the present study area that did not have significant levels of $\mathrm{Zd}, \mathrm{Cd}, \mathrm{Cu}$, and $\mathrm{Pb}$ pollution, whereas $65 \%$ of the stations were heavily polluted with As (Öztürk et al. 2021). Bottom types significantly affected the biometrics of the epiphyte only in winter. De Battisti et al. (2021) estimated that bottom types significantly changed the coverage having higher on rocks than sand as occurred in the present study.

\section{Declarations}

\section{Acknowledgement}

The present study was funded by The Scientific and Technological Research Council of Turkey (TUBITAK) with a grant no: $117 Y 133$ and the samples collected during 2011-2012 was provided within a framework of a project funded by TUBITAK with a grant no: 110Y232. We thanked General Directorate of Fisheries and Aquaculture - Republic of Turkey Ministry of Agriculture and Forestry to give us an official permission to sample Posidonia oceanica under protection. We thanked the crew of R/V Akdeniz Su. 
Funding Erhan Mutlu received funding from Scientific and Technological Research Council of Turkey, TÜBITAK (grant no: $117 Y 133$ and 110Y232).

Conflict of interest The authors have no conflicts of interest to declare that are relevant to the content of this article. On behalf of all authors, the corresponding author states that there is no conflict of interest.

Availability of data and material The data are not shared but the data will be available if requested by the journal.

Code availability all software used in the present study was used with the license of each code.

Ethical approval The authors declare that all applicable guidelines for sampling, care and experimental use of animals in the study have been followed.

Consent to participate All authors declare their participation in the study and the development of the manuscript herein.

Consent for publication All authors have read and approved the final version of the manuscript herein for publication in "Environmental Science and Pollution Research".

\section{CRediT authorship contribution statement}

Erhan Mutlu: Project administration, Funding acquisition, Supervision, Investigation, Software, Data analyzes, Roles/Writing - original draft. Doğukan Karaca: Investigation, Formal analysis, Resources, Data curation. Güler Sıla Duman: Investigation, Formal analysis, Resources, Data curation. Ahmet Şahin: Investigation, Resources. Yaşar Özvarol: Investigation, Resources. Cansu Olguner: Investigation, Formal analysis, Resources, Data curation for surveys during 2011-2012.

Declaration of Competing Interest The authors declare that they have no known competing financial interests or personal relationships that could have appeared to influence the work reported in this paper.

\section{References}

1. APHA (1999) Standard Methods for the Examination of Water and Wastewater. American Public Health Association, Washington DC

2. Baggett LP, Heck KL, Frankovich TA, Armitage AR, Fourqurean JW (2010) Nutrient enrichment, grazer identity, and their effects on epiphytic algal assemblages, field experiments in subtropical turtlegrass Thalassia testudinum meadows. Mar Ecol Prog Ser 406:33-45

3. Balata D, Bertocci I, Piazzi L, Nesti U (2008) Comparison between epiphyte assemblages of leaves and rhizomes of the seagrass Posidonia oceanica subjected to different levels of anthropogenic eutrophication. Estuar Coas Shelf Sci 79:533-540. https://doi.org/10.1016/j.ecss.2008.05.009

4. Balata D, Piazzi L, Nesti U, Bulleri F, Bertocci I (2010) Effects of enhanced loads of nutrients on epiphytes on leaves and rhizomes of Posidonia oceanica. J Sea Res 63:173-179. 
https://doi.org/10.1016/j.seares.2009.12.001

5. Beavington-Penney Simon J, Paul Wright V, Woelkerling Wm J (2004) Recognising macrophytevegetated environments in the rock record: a new criterion using 'hooked' forms of crustose coralline red algae. Sediment Geol 166:1-9. https://doi.org/10.1016/j.sedgeo.2003.11.022

6. Bedini R, Piazzi L (2012) Evaluation of the concurrent use of multiple descriptors to detect anthropogenic impacts in marine coastal systems. Mar Biol Res 8(2):129-140. https://doi.org/10.1080/17451000.2011.615324

7. Bedini R, Canali Mg, Bertuccelli M (2003) Epiphytic communities on Posidonia oceanica (L.) Delile leaves along the north Tyrrhenian coasts (N.W. Mediterranean Sea, Italy). Medit Mar Sci 4(2):99-114. https://doi.org/10.12681/mms.233

8. Ben Brahim M, Hamza A, Hannachi I, Rebai A, Jarboui O, Bouain A, Aleya L (2010) Variability in the structure of epiphytic assemblages of Posidonia oceanica in relation to human interferences in the Gulf of Gabes, Tunisia. Mar Environ Res 70(5):411-421.

http://dx.doi.org/10.1016/j.marenvres.2010.08.005

9. Bermejo R, Fuente Gde la, Ramírez-Romero E, Vergara JJ, Hernández I (2016) Spatial variability and response to anthropogenic pressures of assemblages dominated by a habitat forming seaweed sensitive to pollution (northern coast of Alboran Sea). Mar Poll Bull 105(1):255-264. https://doi.org/10.1016/j.marpolbul.2016.02.017

10. Boudouresque CF, Jeudy de Grissac A, Meinesz A (1984) Relations entre le sedimentation et l'allongement des rhizomes orthotropes de Posidonia oceanica dans la baie d'Elbu (Corse). In: Boudouresque CF, Jeudy de Grissac A Olivier J (eds) International workshop on Posidonia oceanica beds. GIS Posidonie Publishers, Marseille, p 185-191

11. Bradassi $F$ (2011) Determining a threshold in effect of ocean acidification on crustose coralline algae (including a case study to teach at school). PhD Thesis. Università Degli Studi Di Trieste, 144 pp

12. Brahim MB, Mabrouk L, Hamza A, Jribi I (2020) Comparison of spatial scale variability of shoot density and epiphytic leaf assemblages of Halophila stipulacea and Cymodocea nodosa on the Eastern Coast of Tunisia. Plant Biosystems 154(3):413-426. https://doi.org/10.1080/11263504.2019.1674399

13. Casola E, Scardi M, Mazzella L, Fresi E (1987) Structure of the epiphytic community of Posidonia oceanica leaves in a shallow meadow. P.S.Z.N. I. Mar Ecol 8(4):285-296

14. Cox TE, Schenone S, Delille J, Díaz-Castañeda V, Alliouane S, Gattuso J-P, Gazeau F (2015) Effects of ocean acidification on Posidonia oceanica epiphytic community and shoot productivity. J Ecol 103:1594-1609. https://doi.org/10.1111/1365-2745.12477

15. De Battisti D, Balestri E, Pardi G, Menicagli V, Lardicci C (2021) Substrate type influences the structure of epiphyte communities and the growth of Posidonia oceanica seedlings. Front Plant Sci 12:660658. https://doi.org/10.3389/fpls.2021.660658 
16. Duman TY, Robertson AHF, Elmacı H, Kara M (2017) Palaeozoic-Recent geological development and uplift of the Amanos Mountains (S Turkey) in the critically located northwesternmost corner of the Arabian continent. Geodin Acta 29(1):103-138. https://doi.org/10.1080/09853111.2017.1323428

17. Ediger V, Evans G, Ergin M (1997) Recent surficial shelf sediments of the Cilician Basin (Turkey), northeastern Mediterranean. Continent Shelf Res 17(13):1659-1677

18. El-Geziry TM, Bryden IG (2010) The circulation pattern in the Mediterranean Sea: issues for modeller consideration. J Oper Oceanogr 3(2):39-46. https://doi.org/10.1080/1755876X.2010.11020116

19. Fragoso D, Ramírez-Cahero F, Rodríguez-Galván A, Hernández-Reyes R, Heredia A, Rodríguez D, Aguilar-Franco M, Bucio L, Basiuk VA (2010) Characterization of the $\mathrm{CaCO}_{3}$ biomineral in coralline red algae (Corallinales) from the Pacific coast of Mexico. Cienc Mar 36(1):41-58

20. Giovannetti E, Lasagna R, Montefalcone M, Bianchi CN, Albertelli G, Morri C (2008) Inconsistent responses to substratum nature in Posidonia oceanica meadows: An integration through complexity levels? Chem Ecol 24(S1):83-91. https://doi.org/10.1080/02757540801966439

21. Gündoğdu S, Çevik C (2017) Micro- and mesoplastics in Northeast Levantine coast of Turkey: The preliminary results from surface samples. Mar Poll Bull 118(1-2):341-347.

https://doi.org/10.1016/j.marpolbul.2017.03.002

22. Havelange S, Lepoint G, Dauby P, Bouquegneau JM (1997) Feeding of the sparid fish Sarpa salpa in a seagrass ecosystem: Diet and carbon flux. PSZNI Mar Ecol 18:289-297

23. Heck KL, Valentine JF, Pennock JR, Chaplin G, Spitzer PM (2006) Effects of nutrient enrichment and grazing on shoalgrass Halodule wrightii and its epiphytes, results of a field experiment. Mar Ecol Prog Ser 326:145-156

24. Heck J, Valentine JF (2006) Plant-herbivore interactions in seagrass meadows. J Exp Mar Biol Ecol 330:420-436

25. Jacquemart J, Demoulin V (2008) Comparison of the epiphytic macroflora of Posidonia oceanica leaves in different meadows of the western Mediterranean. Flora Mediterr 18:393-420

26. Jaschinski S, Sommer U (2008) Top-down and bottom-up control in an eelgrass-epiphyte system. Oikos 117:754-762

27. Kamenos NA, Perna G, Gambi MC, Micheli F, Kroeker KJ (2016) Coralline algae in a naturally acidified ecosystem persist by maintaining control of skeletal mineralogy and size. Proc Royal Soc B 283(1840):11-59. https://doi.org/10.1098/rspb.2016.1159

28. Kjøsterud AB (1997) Epiphytic coralline crusts (Corallinales, Rhodophyta) from South Norway. Sarsia 82(1):23-37. https://doi.org/10.1080/00364827.1997.10413635

29. Lepoint G, Cox AS, Dauby P, Poulicek M, Gobert S (2006) Food sources of two detritivore amphipods associated with the seagrass Posidonia oceanica leaf litter. Mar Biol Res 2:355-365

30. Lepoint G, Jacquemart J, Bouquegneau J-M, Demoulin V, Gobert S (2007) Field measurements of inorganic nitrogen uptake by epiflora components of the seagrass Posidonia oceanica 
(Monocotyledons, Posidoniaceae). J Phycol 43:208-218. https://doi.org/10.1111/j.15298817.2007.00322.x

31. Lepoint G, Nyssen F, Gobert S, Dauby P, Bouquegneau JM (2000) Relative impact of a seagrass bed and its adjacent epilithic algal community in consumer diets. Mar Biol 136:513-518

32. Lorenzen CJ (1967) Determination of chlorophyll and phaeopigments: spectrophotometric equations. Limnol Oceanogr 12(2):343-346

33. Mabrouk L, Asma H, Bradai MN (2017) Temporal and bathymetric variation on of epiphyte cover and leaf biomass in a southern Posidonia oceanica (L.) meadow: The case of Mahdia coast, Tunisia. Mar Ecol 38:e12394. https://doi.org/10.1111/maec.12394

34. Mabrouk L, Hamza A, Brahim MB, Bradai M-N (2013) Variability in the structure of epiphyte assemblages on leaves and rhizomes of Posidonia oceanica in relation to human disturbances in a seagrass meadow off Tunisia. Aquat Bot 108:33-40. http://doi.org/10.1016/j.aquabot.2013.03.002

35. Mabrouk L, Brahim MB, Hamza A, Bradai M-N (2015) Temporal and spatial zonation of macroepiphytes on Posidonia oceanica (L.) Delile leaves in a meadow off Tunisia. Mar Ecol 36:7792. https://doi.org/10.1111/maec.12118

36. Mabrouk L, Brahim MB, Hamza A, Bradai M-N (2014) Diversity and temporal fluctuations of epiphytes and sessile invertebrates on the rhizomes Posidonia oceanica in a seagrass meadow off Tunisia. Mar Ecol 35:212-220. https://doi.org/10.1111/maec.12072

37. Maida GDi, Tomasello A, Sciandra M, Pirrotta M, Milazzo M, Calvo S (2013) Effect of different substrata on rhizome growth, leaf biometry and shoot density of Posidonia oceanica. Mar Environ Res 87-88:96-102. https://doi.org/10.1016/j.marenvres.2013.04.001

38. Mann S (2001) Biomineralization: Principles and Concepts in Bioinorganic Materials Chemistry. Oxford University Press, New York

39. Martin S, Rodolfo-Metalpa R, Ransome E, Rowley S, Buia M-C, Gattuso J-P, Hall-Spencer J (2008) Effects of naturally acidified seawater on seagrass calcareous epibionts. Biol Lett 4:689-692. https://doi.org/10.1098/rsbl.2008.0412

40. Martinez-Crego B, Prado P, Alcoverro T, Romero J (2010) Composition of epiphytic community of Posidonia oceanica as a tool for environmental biomonitoring. Estuar Coast Shelf Sci 88:199-208

41. Montefalcone M, Vacchi M, Carbone C, Cabella R, Schiaffino CF, Elter FM, Morri C, Bianchi CN, Ferrari M (2016) Seagrass on the rocks: Posidonia oceanica settled on shallow-water hard substrata withstands wave stress beyond predictions. Estuar Coast Shelf Sci 180:114-122. https://doi.org/10.1016/j.ecss.2016.06.024

42. Mutalipassi M, Fink P, Maibam C, Porzio L, Buia MC, Gambi MC, Patti FP, Scipione MB, Lorenti M, ZupoV (2020) Ocean acidification alters the responses of invertebrates to wound-activated infochemicals produced by epiphytes of the seagrass Posidonia oceanica. J Exp Mar Biol Ecol. 530. https://doi.org/10.1016/j.jembe.2020.151435. 531

43. Mutlu E, Balaban C, Gokoglu M, Ozvarol Y, Olguner MT (2014) Acoustical density-dependent calibration of the dominant sea meadows and seagrasses and monitoring of their distribution. 
TUBITAK project final report 110Y232:368

44. Mutlu E, Özvarol Y, Şahin A, Duman GS, Karaca D (2020a) Acoustical determination of biomass quantities and monitoring of distribution of Posidonia oceanica meadows on the Turkish entire coasts in the Eastern Mediterranean. TUBITAK project final report 117Y133:190

45. Mutlu E, Özvarol Y, Şahin A, Duman GS, Karaca D (2020b) Macro litter distribution of the Turkish Mediterranean coasts dominated by pleasure crafts. Mar Poll Bull 151:110833. https://doi.org/10.1016/j.marpolbul.2019.110833

46. Nesti U, Piazzi L, Balata D (2009) Variability in the structure of epiphytic assemblages of the Mediterranean seagrass Posidonia oceanica in relation to depth. Mar Ecol 30:276-287. https://doi.org/10.1111/j.1439-0485.2008.00275.x

47. Olguner MT, Olguner C, Mutlu E, Deval MC (2018) Distribution and composition of benthic marine litter on the shelf of Antalya in the eastern Mediterranean. Mar Pollut Bull 136:171-176. https://doi.org/10.1016/j.marpolbul.2018.09.020

48. Öztürk R, Gedik K, Şahin A, Özvarol Y, Mutlu E (2021) Comparative trace element trends in Posidonia oceanica and its sediments along the Turkish-Mediterranean Sea coast. Environ Sci Pollut Res. https://doi.org/10.1007/s11356-021-15089-6

49. Penrose D, Chamberlain YM (1993) Hydrolithon farinosum (Lamouroux) comb. nov.: implications for generic concepts in the Mastophoroideae (Corallinaceae, Rhodophyta). Phycologia 32(4):295-303

50. Peterson BJ, Frankovich TA, Zieman JC (2007) Response of seagrass epiphyte loading to field manipulations of fertilization, gastropod grazing and leaf turnover rates. J Exp Mar Biol Ecol 34:6172. https://doi.org/10.1016/j.jembe.2007.04.012

51. Piazzi L, Balata D, Cinelli F, Benedetti-Cecchi L (2004) Patterns of spatial variability in epiphytes of Posidonia oceanica. Differences between a disturbed and two reference locations. Aquat Bot 79:345-356

52. Piazzi L, Acunto S, Cinelli F (2000) Mapping of Posidonia oceanica beds around Elba Island (western Mediterranean) with integration of direct and indirect methods. Oceanol Acta 23:339-346

53. Piazzi L, Balata D, Cinelli F (2002) Epiphytic macroalgal assemblages of Posidonia oceanica rhizomes in the western Mediterranean. European J Phycol 37(1):69-76. https://doi.org/10.1017/S0967026201003432

54. Poulain P-M, Bussani A, Gerin R, Jungwirth R, Mauri E, Menna M, Notarstefano G (2013) Mediterranean surface currents measured with drifters: From basin to subinertial scales. Oceanography 26(1):38-47. https://doi.org/10.5670/oceanog.2013.03

55. Prado P, Alcoverro T, Martínez-Crego B, Vergés A, Pérez M, Romero J (2007) Macrograzers strongly influence patterns of epiphytic assemblages in seagrass meadows. J Exp Mar Biol Ecol 350:130143. https://doi.org/10.1016/j.jembe.2007.05.033

56. Prado $P$ (2018) Seagrass epiphytic assemblages are strong indicators of agricultural discharge but weak indicators of host features. Estuar Coast Shelf Sci 204:140-148. https://doi.org/10.1016/j.ecss.2018.02.026 
57. Prado T, Alcoverro T, Romero J (2008) Seasonal responses of Posidonia oceanica epiphyte assemblages to nutrient increase. Mar Ecol Prog Ser 359:89-98

58. Radeff G, Schildgen TF, Cosentino D, Strecker MR, Cipollari P, Darbaş G, Gürbüz K (2017) Sedimentary evidence for late Messinian uplift of the SE margin of the Central Anatolian Plateau: Adana Basin, southern Turkey. Basin Res 29:488-514

59. ReyesJ, Afonso-Carrillo J (1995) Morphology and distribution of nongeniculate coralline algae (Corallinaceae, Rhodophyta) on the leaves of the seagrass Cymodocea nodosa (Cymodoceaceae). Phycol 34(3):179-190

60. Reyes J, Sanson M (1997) Temporal Distribution and Reproductive Phenology of the Epiphytes on Cymodocea nodosa Leaves in the Canary Islands. Bot Mar 40:193-201

61. Reyes J, Sanson M, Alfonso-Carrillo J (1998) Distribution of the epiphytes along the leaves of Cymodocea nodosa in the Canary Islands. Bot Mar 41:543-551

62. Sfriso A, Buosi A, Facca C, Sfriso AA (2017) Role of environmental factors in affecting macrophyte dominance in transitional environments: The Italian lagoons as a study case. Mar Ecol 38:e12414. https://doi.org/10.1111/maec.12414

63. Sfriso A, Facca C, Ghetti PF (2009) Validation of the Macrophyte Quality Index (MaQI) set up to assess the ecological status of Italian marine transitional environments. Hydrobiologia 617:117-141

64. Sfriso A, Buosi A, Wolf MA, Sciuto K, Molinaroli E, Moro I, Mistri M, Munari C, Sfriso AA (2020) Microcalcareous seaweeds as sentinels of trophic changes and $\mathrm{CO}_{2}$ trapping in transitional water systems. Ecol Indic 118:106692. https://doi.org/10.1016/j.ecolind.2020.106692

65. Sfriso A, Facca C, Bon D, Buosi A (2016) Macrophytes and ecological status assessment in the Po delta transitional systems, Adriatic Sea (Italy). Application of Macrophyte Quality Index (MaQI). Acta Adriat 57(2):209-226

66. Sfriso A, Facca C, Ghetti PF (2007) Rapid Quality Index, based mainly on Macrophyte Associations (R-MaQI), to assess the ecological status of the transitional environments. Chem Ecol 23(6):1-11

67. Sfriso A, Facca C, Bonometto A, Boscolo R (2014) Compliance of the macrophyte quality index (MaQI) with the WFD (2000/60/EC) and ecological status assessment in transitional areas: The Venice lagoon as study case. Ecol Indic 46:536-547. https://doi.org/10.1016/j.ecolind.2014.07.012

68. Sghaier YR, Zakhama-Sraieb RYM, Charfi-Cheikhrouha F (2013) Patterns of shallow seagrass (Posidonia oceanica) growth and flowering along the Tunisian coast. Aquat Bot 104:185-192. https://doi.org/10.1016/j.aquabot.2011.09.006

69. Sisma-Ventura G, Bialik OM, Yam R, Herut B, Silverman J (2017) $\mathrm{CO}_{2}$ variability in the surface waters of the ultra-oligotrophic Levantine Sea: Exploring the air-sea $\mathrm{CO}_{2}$ fluxes in a fast warming region. Mar Chem 196:13-23p

70. Sol D, Maspons J, Vall-Llosera M, Bartomeus I, Garcia-Pena GE, Pinol J, Freckleton RP (2012) Unraveling the life history of successful invaders. Science 337:580-583 
71. Tsirika A, Skoufas G, Haritonidis S (2007) Seasonal and bathymetric variations of epiphytic macroflora on Posidonia oceanica (L.) Delile leaves in the National Marine Park of Zakynthos (Greece). Mar Ecol 28(S1):146-153

72. Vizzini S, Sara G, Michener RH, Mazzola A (2002) The role and contribution of the seagrass Posidonia oceanica (L.) Delile organic matter for secondary consumers as revealed by carbon and nitrogen stable isotope analysis. Acta Oecol 23:277-285

73. Walker DI, Woelkerling WJ (1988) Quantitative study of sediment contribution by epiphytic coralline red algae in seagrass meadows in Shark Bay, Western Australia. Mar Ecol Prog Ser 43:71-77

74. Walsh-Kennedy S, Aksu AE, Hall J, Hiscott RN, Yaltırak C, Çifçi G (2014) Source to sink: The development of the latest Messinian to Pliocene-Quaternary Cilicia and Adana Basins and their linkages with the onland Mut Basin, eastern Mediterranean. Tectonophysics 622:1-21

\section{Figures}



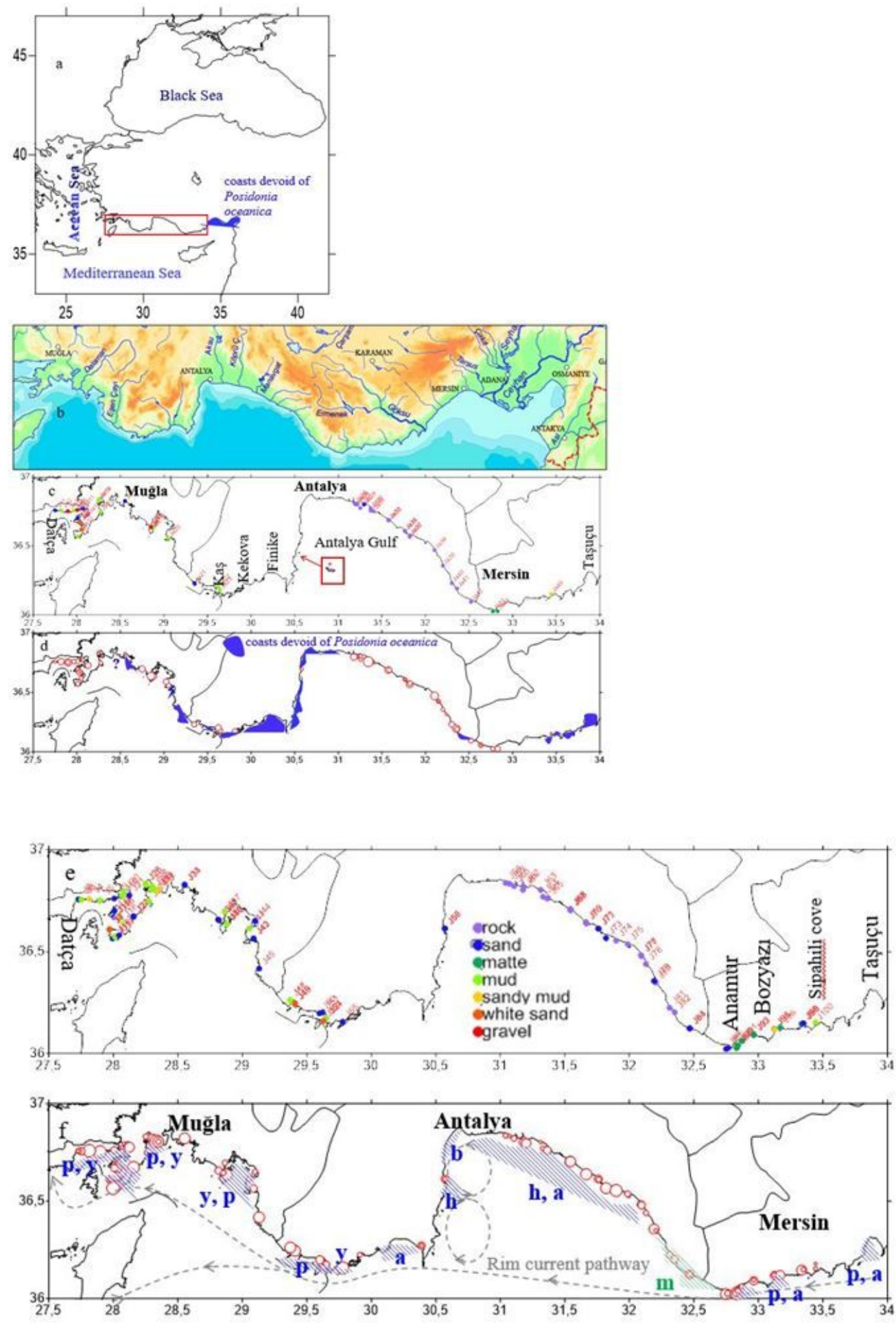

\section{Figure 1}

Study area (a; red frame), and the streams flowing to the Turkish Mediterranean waters (b, from http://www.beycan.net/eklenen/nehirler/Akarsular-2068x1051.png) and sampling stations classified by the bottom types and bottom depth (red circle; min: $5 \mathrm{~m}$ and max: $52 \mathrm{~m}$ ) in December 2018/January 2019 (c and d, respectively) and June/July 2019 (e and f, respectively) and anthropogenic sources from the land: p; small-capacity hotel, and pension, a; intensive agricultures on land, h; very high capacity of 
hotel, b; metropolitan beach activities; intensive activities of yachting and pleasure crafts, m; very coastal intensive agriculture of banana in the crossed-area along the Turkish Mediterranean Sea coast.

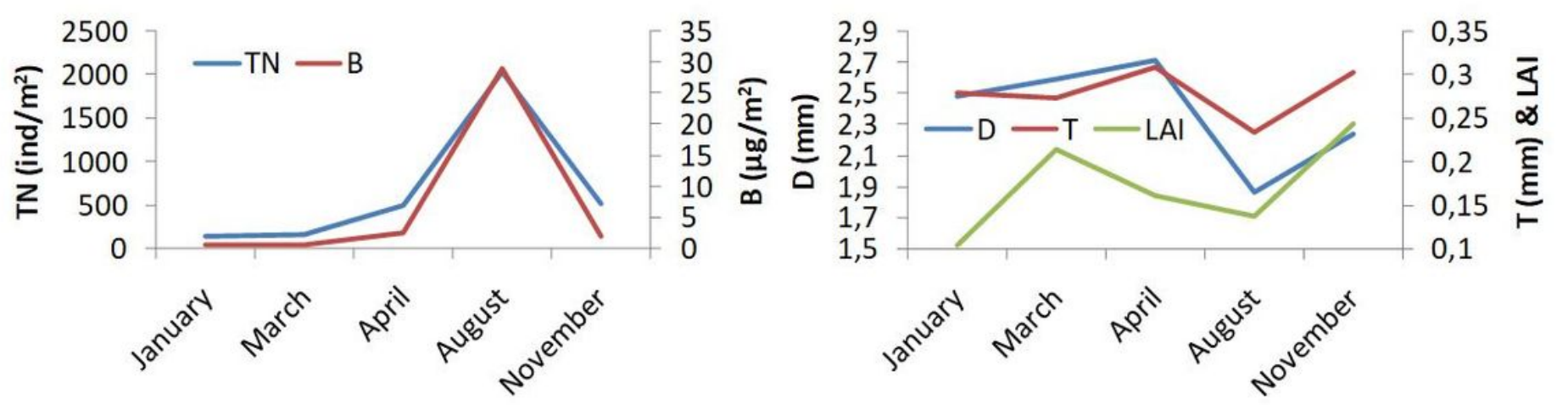

\section{Figure 2}

Temporal distribution of the biometrics of Pneophyllum fragile found on leave, and LAI of Cymodocea nodosa in January-August of year 2012, and November 2011.

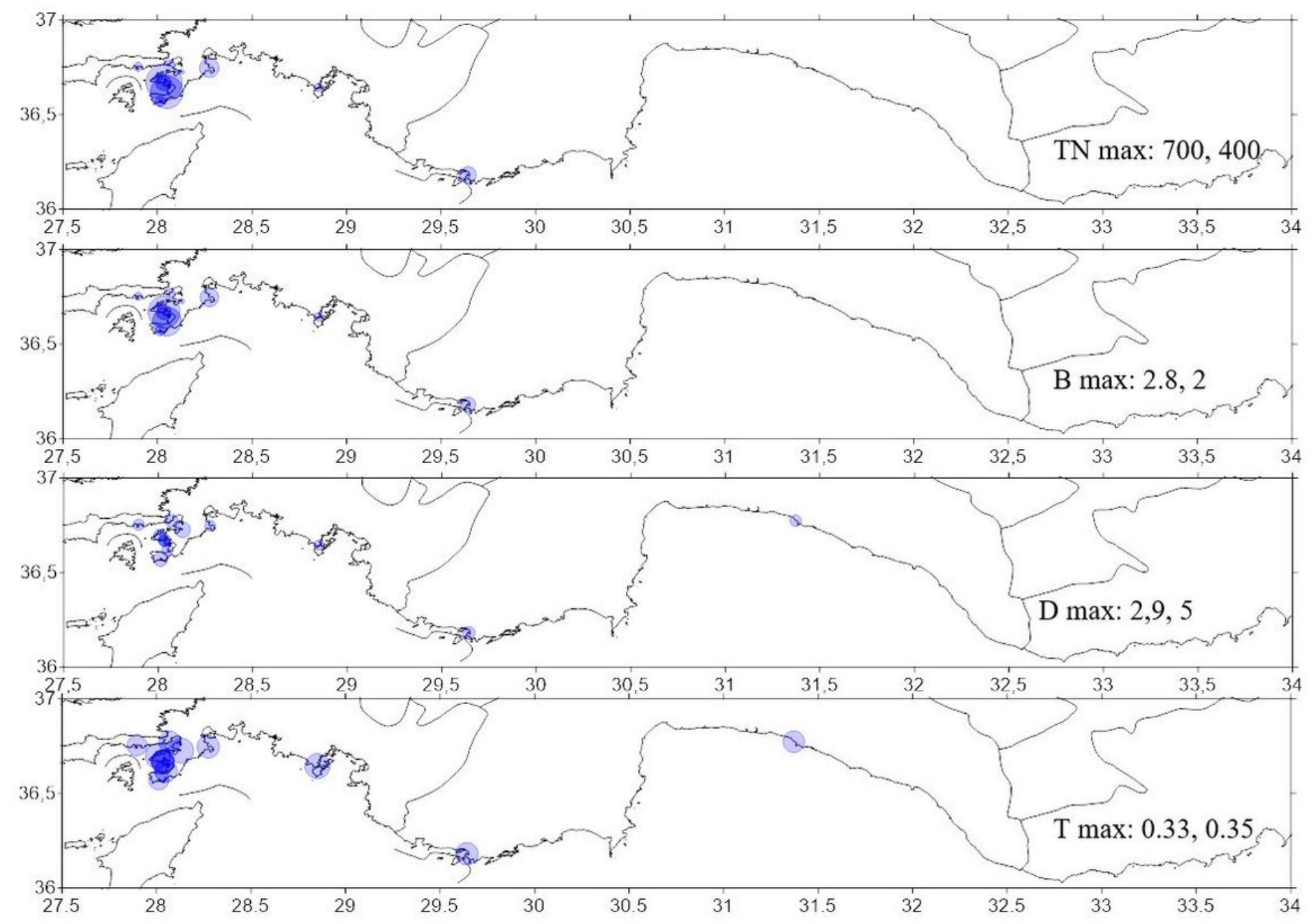




\section{Figure 3}

Biometrical distribution of Hydrolithon boreale; abundance ( $T N$; ind/m2), biomass (B; $\mu \mathrm{g} / \mathrm{m} 2)$, crust diameter $(\mathrm{D} ; \mathrm{mm})$, and thickness $(T ; \mathrm{mm})$ in winter. Maximum values were maximum values of the winter survey, and scaling value for the circles in both winter, and summer in Figure 4, respectively.
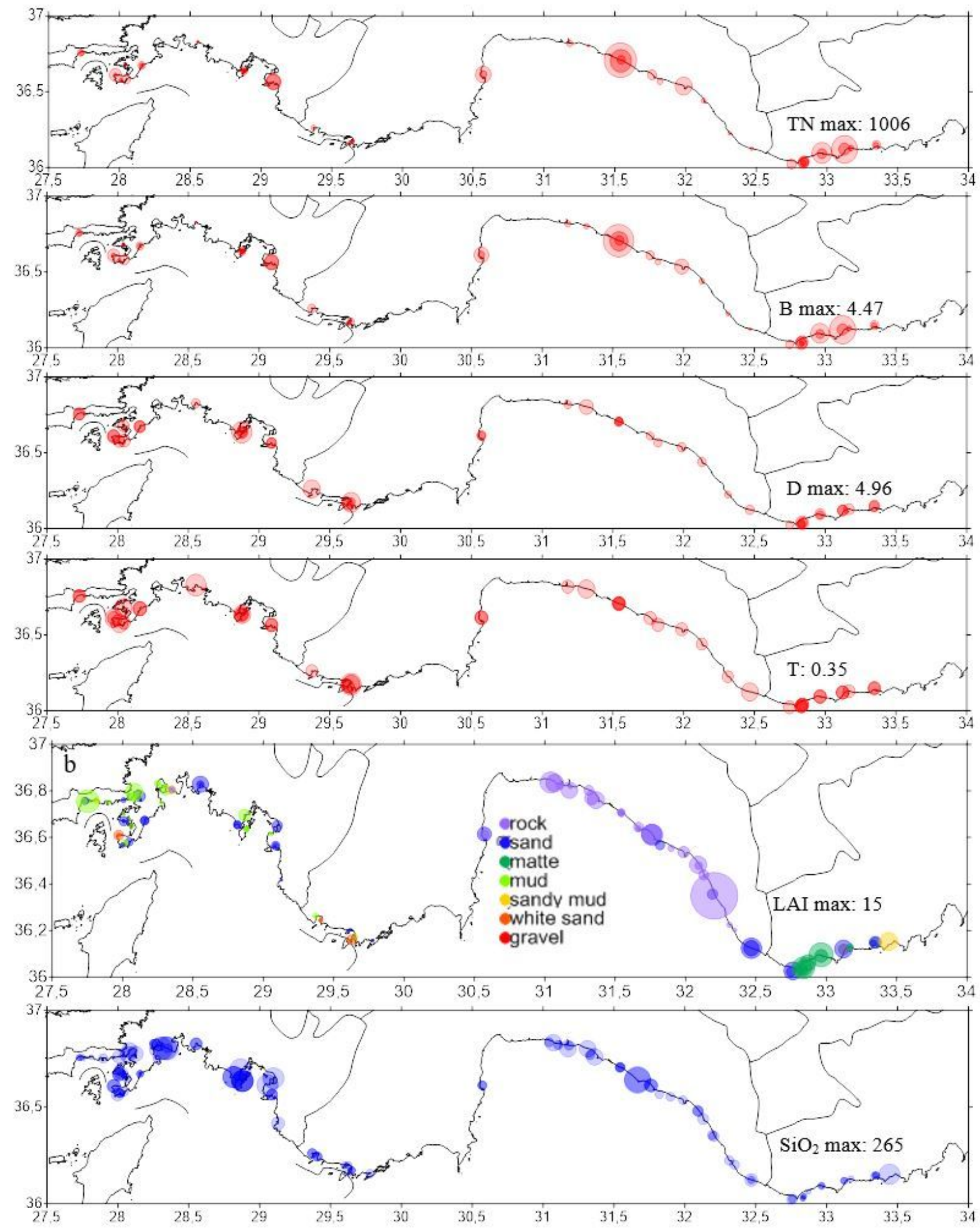

Figure 4 
Biometrical distribution of Hydrolithon boreale; abundance ( $T N$; ind/m2), biomass ( $B ; \mu \mathrm{g} / \mathrm{m} 2)$, crust diameter ( $\mathrm{D} ; \mathrm{mm})$, and thickness ( $\mathrm{T} ; \mathrm{mm})$, and LAl of Posidonia oceanica and sea surface concentration of $\mathrm{SiO} 2(\mu \mathrm{M})$ in summer. Maximum value was maximum values of the summer.
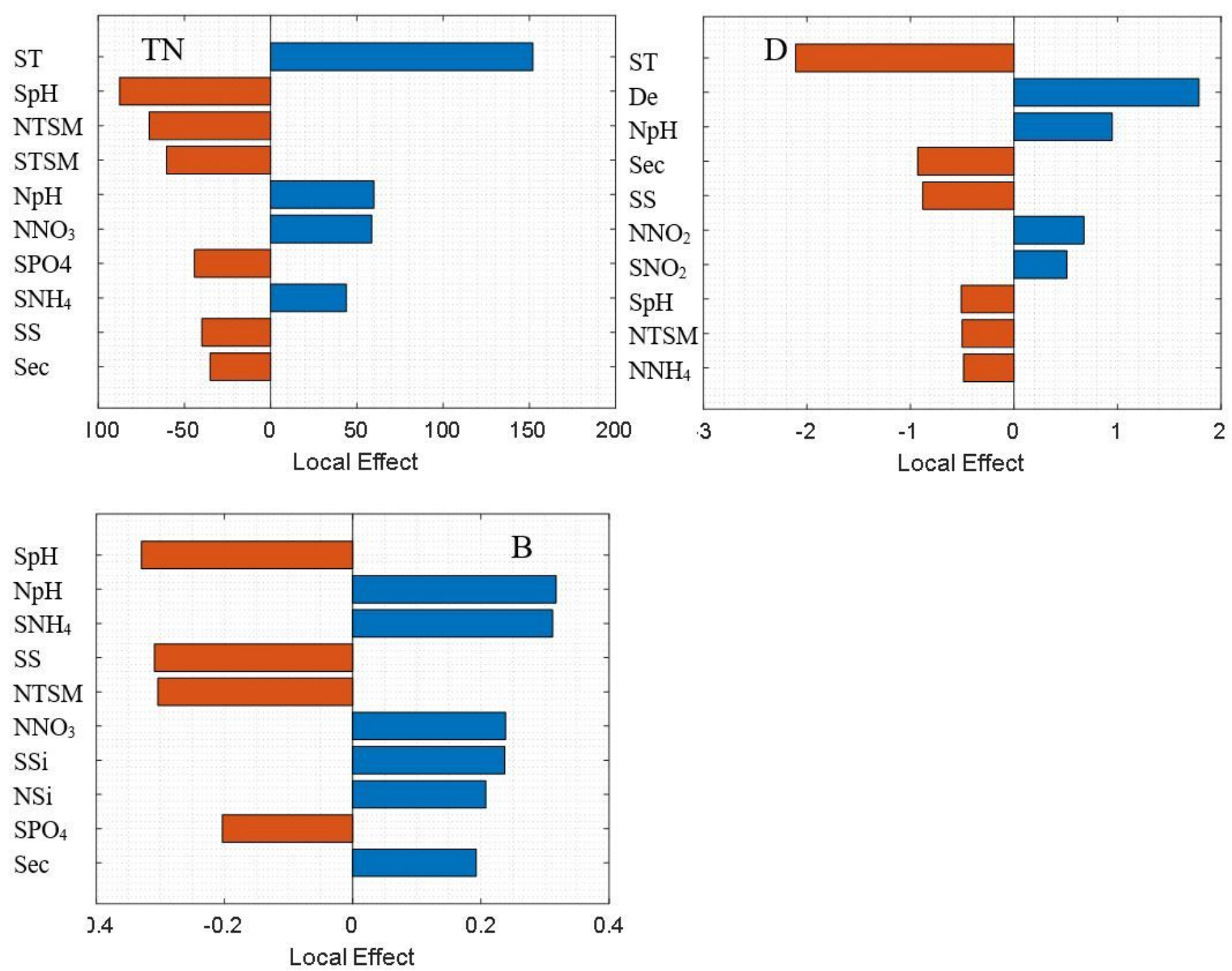

Figure 5

The GAM solution to estimate effective variables from all environmental parameters (see Table 6 for the abbreviations) on the biometrics (Abundance; TN, D; crust diameter, and biomass, B) of the epiphyte in summer. 

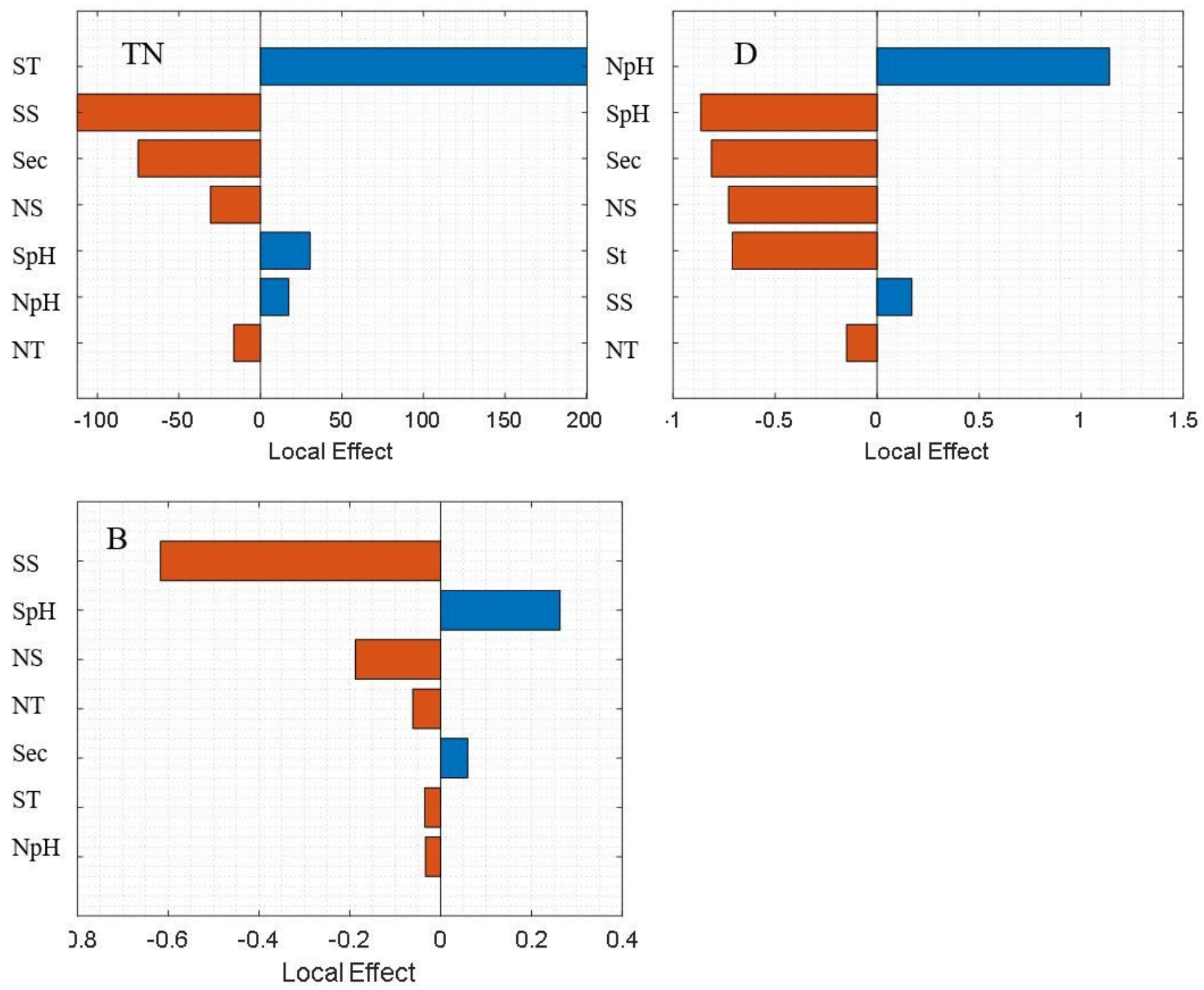

Figure 6

The GAM solution to estimate effective variables from only physical environmental parameters (see Table 6 for the abbreviations) on the biometrics (Abundance; TN, D; crust diameter, and biomass, B) of the epiphyte in summer. 

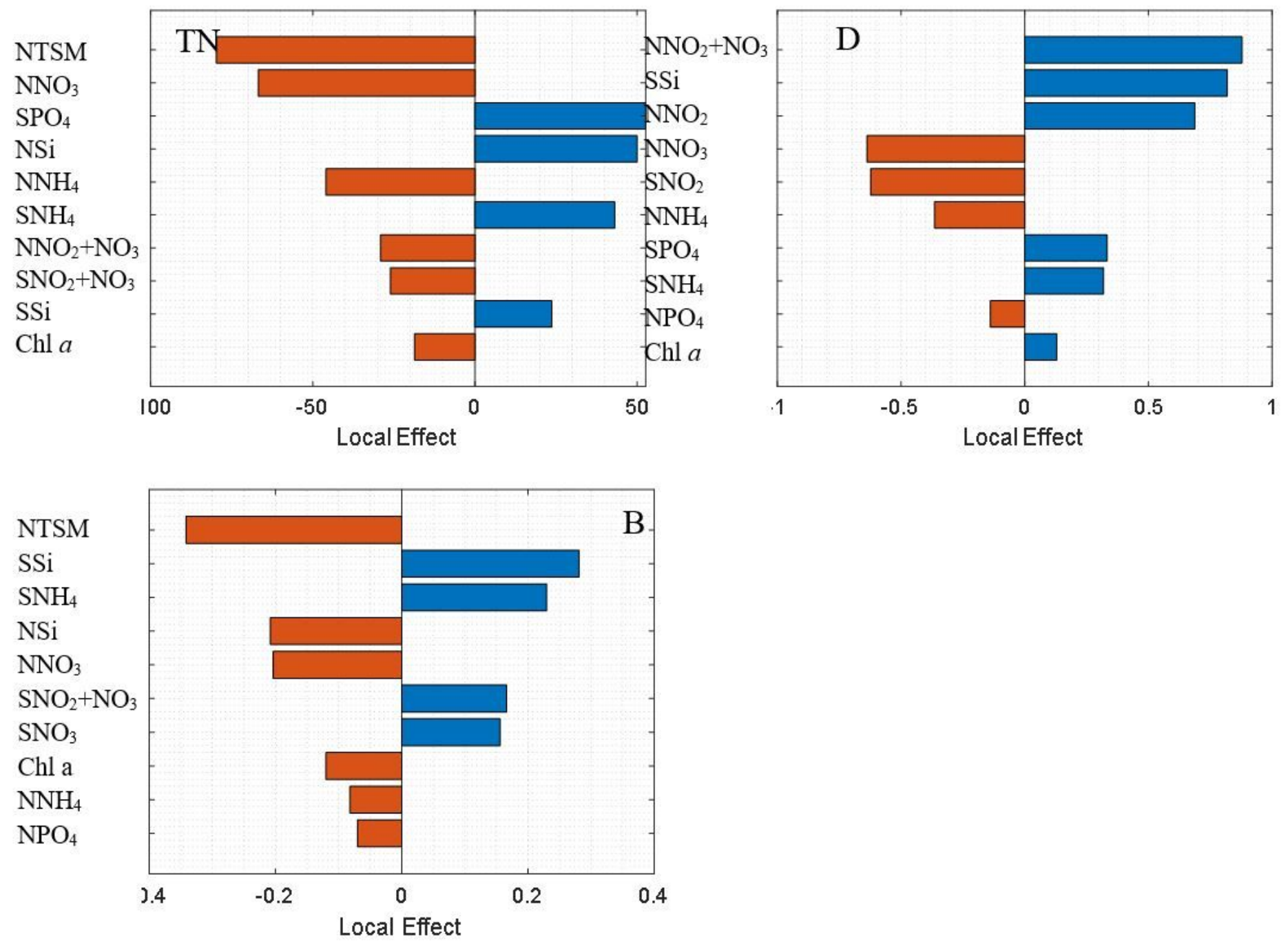

Figure 7

The GAM solution to estimate effective variables from only chemical environmental parameters (see Table 6 for the abbreviations) on the biometrics (Abundance; TN, D; crust diameter, and biomass, B) of the epiphyte in summer. 

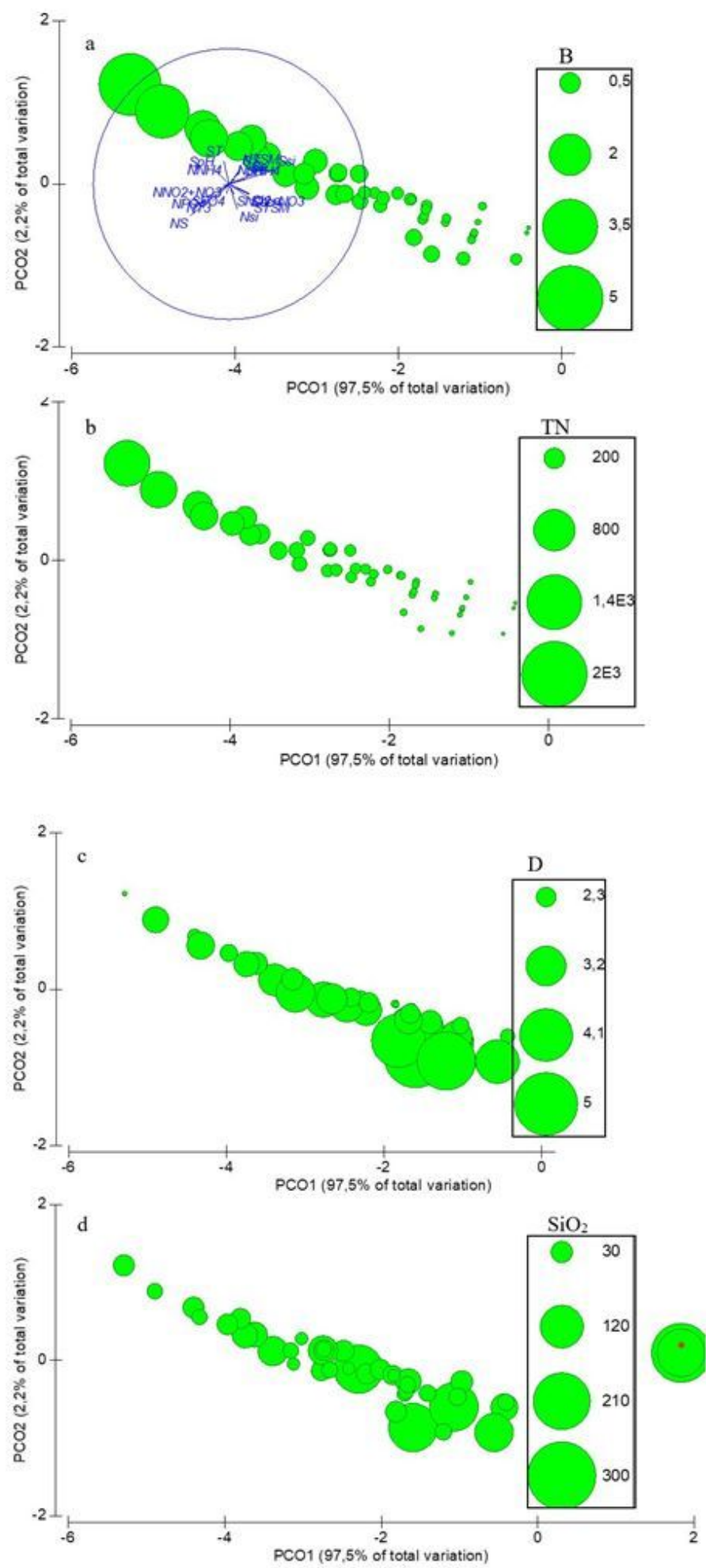

\section{Figure 8}

The PCO solution of the biometrics and correlation with the environmental parameters. Distribution of the biomass $(B, \mu \mathrm{g} / \mathrm{m} 2)$, abundance (TN, ind/m2), crust diameter $(\mathrm{D}, \mathrm{mm})$ of the epiphyte, and SSi $(\mu \mathrm{M})$ of the environmental parameter overlapped on the ordination of the PCO in summer. * denotes locations where the epiphyte is absent (a-d). 


\section{Supplementary Files}

This is a list of supplementary files associated with this preprint. Click to download.

- Appendices.docx 